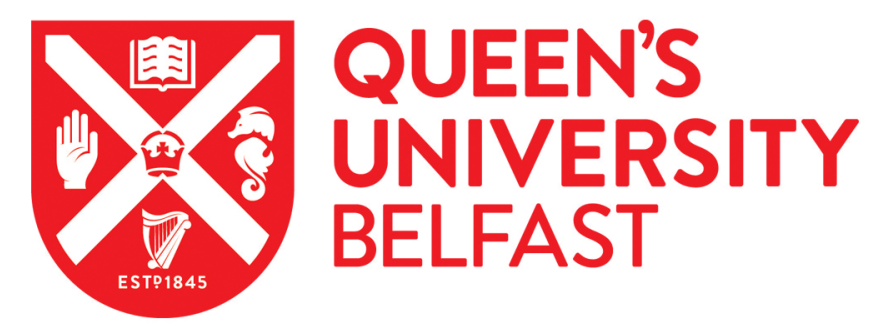

\title{
Managing the Entanglement: Complexity Leadership in Public Sector Systems
}

Murphy, J., Rhodes, M. L., Meek, J., \& Denyer, D. (2017). Managing the Entanglement: Complexity Leadership in Public Sector Systems. Public Administration Review, 77(5), 692. https://doi.org/10.1111/puar.12698

Published in:

Public Administration Review

Document Version:

Peer reviewed version

Queen's University Belfast - Research Portal:

Link to publication record in Queen's University Belfast Research Portal

Publisher rights

(c) 2016 Wiley \& Sons.

This work is made available online in accordance with the publisher's policies. Please refer to any applicable terms of use of the publisher.

\section{General rights}

Copyright for the publications made accessible via the Queen's University Belfast Research Portal is retained by the author(s) and / or other copyright owners and it is a condition of accessing these publications that users recognise and abide by the legal requirements associated with these rights.

Take down policy

The Research Portal is Queen's institutional repository that provides access to Queen's research output. Every effort has been made to ensure that content in the Research Portal does not infringe any person's rights, or applicable UK laws. If you discover content in the Research Portal that you believe breaches copyright or violates any law, please contact openaccess@qub.ac.uk. 


\section{Managing the Entanglement: Complexity Leadership in Public}

\section{Sector Systems}

Joanne Murphy, Queen's University, Belfast (UK)

Postal Address: Queen’s Management School, Riddell Hall, 185 Stranmillis Road,

Belfast. BT9 5EE

Email: Joanne.Murphy@qub.ac.uk

Dr Joanne Murphy is a Lecturer in Organizational Change in the Management School, Queen's University, and a Fellow in the George J. Mitchell Institute for Global Peace, Security and Justice. Her research focuses on leadership and organizational change, especially institutional change in post conflict environments. She has written extensively on change after conflict.

\section{Mary Lee Rhodes, Trinity College (Ireland)}

Postal Address: School of Business, Trinity College, College Green, Dublin 2, Ireland Email: rhodesml@tcd.ie

Mary Lee Rhodes is an Associate Professor of Public Management at Trinity College, Dublin. Her research is focused on complexity, public service systems and the 
dynamics of performance. Prof. Rhodes has published numerous articles on housing as a complex adaptive system and her recent book on Complexity and Public Management was published by Routledge in 2011. Her current research is on the nature and dynamics of social impact, social innovation and social finance.

\section{Jack Meek, University of La Verne (USA)}

Postal Address: Department of Public Administration, College of Business and Public Management, University of La Verne, 1950 Third Street, La Verne, CA 91750

Email: jmeek@laverne.edu

Jack W. Meek, Ph.D. is a University of La Verne Academy Professor and Professor of Public Administration at the College of Business and Public Management at the University of La Verne where he serves as Director of the Center for Research. Professor Meek offers courses in research methods and collaborative public management. His research focuses on metropolitan governance including the emergence of local and regional collaboration and partnerships, policy networks and citizen engagement.

\section{David Denyer, Cranfield University (UK)}

Postal Address: Cranfield School of Management, College Road, Cranfield, MK43 OAL

Email: David.Denyer@cranfield.ac.uk 
David Denyer is Professor Leadership and Organizational Change at Cranfield School of Management. He has an international reputation for his research on leadership in extreme contexts, organizational resilience and evidence-based management. David has published a large number of important and highly cited articles and book chapters and regularly speaks at international conferences and high profile events. David has also made a substantial contribution outside academia through strategic and policy advisory roles. 


\section{Practitioner Points}

- The multiplicity of actors, contexts and objectives in complex public administration projects present distinct challenges to leaders in this sector, requiring a nuanced set of leadership behaviourspractices.

- Evidence from this study suggests that in low complexity environments administrative leadership practices such as directing, planning and resourcing are common. In medium complexity environments, administrative leadership was still present while adaptive practices, such as the inclusion of diverse skills and perspectives appear to be important,-_along with enabling practices such as disrupting existing patterns and assumptions and giving meaning 0 events.

- Adaptive and enabling-practices were observed to the greatest extent in the most complex cases, outnumbering administrative practices over 2 to 1 . The need to actively support the inclusion of diverse skills / perspectives (including boundary spanning) was dominant, but other adaptive practices such as stimulating innovative ideas and changing plans, processes and routines also featured to a greater extent than in the medium complexity cases.

- The significant contribution of this paper is evidence of the role of enabling leadership in managing the tensions created by the need to achieve both'dualities' in the enabling leadership behaviors that are required to maintain a sense of stability in order to coordinate, structure and control 
organizational activity (administrative) and as as generate-the conditions

for innovation, change and transformation (adaption). The paper shows that

administrative and adaptive practices need not be mutually exclusive or

interfering conflicting but can enable each other.

- Greater attention needs to be paid to the tensions inherent in enabling

leadership if actors are to cope with the complex, collaborative cross boundary work in which they are increasingly engaged.
Formatted: Font: Times New Roman, $12 \mathrm{pt}$

Formatted: Font: Times New Roman, $12 \mathrm{pt}$

Formatted: Font: Times New Roman, $12 \mathrm{pt}$

Formatted: Font: Times New Roman, 12 pt, English (United Kingdom) 


\title{
Managing the Entanglement: Complexity Leadership in Public
}

\section{Sector Systems}

\author{
Abstract \\ Complexity in public sector systems requires leaders to balance the administrative \\ practices necessary to be aligned and efficient in the management of routine \\ challenges, and the adaptive practices required to respond to dynamic circumstances. \\ Conventional notions of leadership in the field of public administration do not fully \\ explain the role of leadership in balancing the entanglement of formal, top-down, \\ administrative functions and informal, emergent, adaptive functions within public \\ sector settings with different levels of complexity. Drawing on and extending \\ existing complexity leadership constructs, this paper explores how leadership is \\ enacted over the duration of six urban regeneration projects, representing high, \\ medium and low levels of project complexity. The study suggests that greater \\ attention needs there-to be paid to are-the 'dualities' present within enabling practices \\ and greater attention needs to be paid to the tensions inherent in these-enabling \\ leadership practices-if actors are to cope with the complex, collaborative, cross- \\ boundary, adaptive work in which they are increasingly engaged.
}


Managing the Entanglement: Complexity Leadership in Public Sector Systems

Public administration and leadership scholars express growing concerns that existing models of leadership may not fully capture the leadership dynamics operating in today’s complex environments (McKelvey and Lichtenstein, 2007). In a recent issue of Public Administration Review, authors (Van Wart, 2013; Hansen, 2013;

Nalbandian, O’Neil, Wilkes and Kaufman, 2013) emphasized the importance of leadership processes in enabling change and transformation in complex public sector systems, yet many of these studies drew on leadership constructs based on "classical management and role theory” (Van Wart, 2013: 553). In the $21^{\text {st }}$ century, the multiplicity of actors, contexts and paradigmatic shifts in public administration present distinct challenges to leadership (Terry, 1995; Van Wart, 2003; Heifetz, Linsky and Grashow, 2009). Leadership is “embedded in a complex interplay of numerous interacting forces” (Uhl-Bien, Marion and McKelvey, 2007: 302). Unstable times and crises increase distractions and often require unique approaches (Boin and Otten, 1996; Wheatley, 2006; Van Wart 2003). It is, therefore, unsurprising that researchers have struggled to come to terms with the empirical realities and the subtlety of exploring leadership behaviorspractices in such "tangled" environments (Van Wart, 2003).

Recent research on complexity leadership has challenged traditional notions of leadership by shifting attention away from the characteristics of leaders and the 
actions of individuals towards the relational, dynamic, distributed nature of leadership processes (Uhl-Bien, 2006; Uhl-Bien et al., 2007). The complexity perspective suggests that leadership is required to maintain a sense of stability in order to coordinate, structure and control organizational activity as well as generate the conditions for innovation, change and transformation (Uhl-Bien, et al., 2007). This requires enabling leadership (Uhl-Bien, et al., 2007) to ensure an appropriate balance of these administrative (formal) and adaptive (informal) functions (Selznick, 1949). While complexity leadership offers a new understanding of leadership processes, the literature is largely conceptual, and has not yet adequately addressed leadership at various levels of systems complexity (Lichtenstein and Plowman, 2009) or studied ongoing public-sector contexts. This article aims to address these gaps. The cases presented offer a particularly rich data set to identify leadership processes across broadly similar public sector projects, but carried out in contexts with different levels of complexity. By examining six case studies in urban regeneration in Belfast (Northern Ireland, UK) and Dublin (Republic of Ireland), this article focuses on exploring leadership processes-practices empirically in an effort to understand how leadership is enacted in public sector systems.

We begin by discussing and challenging the existing literature on leadership in public administration. We then draw on the literature on complexity leadership to build a theoretical framework and provide our research questions. To address our first research question we classify the six urban regeneration projects in terms of complexity defined by the diversity of the urban regeneration project and its duration. Following a description of our research methods, we report our findings showing the instances of adaptive, administrative and enabling leadership by level of project complexity. To address our second research question, the main body of the article is 
concerned with a qualitative examination of the tensions inherent in enabling

leadership in the six cases. We conclude with implications for leadership theory, practice and development.

\section{Rethinking public sector leadership - a review of the literature}

Although there has been a number of important studies on leadership in the field of public administration (see e.g. Fernandez, 2005; Kim, 2002; Terry, 2002; Wright and Pandey, 2010), compared to the mainstream organizational literature, leadership theory has generally received less attention (Hansen and Villadsen, 2010). As a result, there are few large-scale empirical studies of public sector leadership (Trottier, Van Wart and Wang, 2008) and increasing calls to further embed public leadership research within leadership studies (Ospina and Wagner, in press). Studies of public sector leadership tend to draw on a range of perspectives including classical management and role theory, transactional leadership theory, transformational leadership theory, horizontal or collaborative leadership theory and ethical and critical leadership theory (Van Wart, 2013). Yet, despite this apparent pluralism, the public administration literature has lagged behind the mainstream organizational literature in challenging some of the basic assumptions of traditional leadership theory. New conceptualizations of leadership, drawing on complexity science, are emerging in the mainstream organizational literatures that have much to offer public administration.

Traditional leadership theory, in both public administration and organizational literatures, has largely been concerned with a focus on leaders and the actions of individuals rather than the dynamic, complex systems, processes and practices that comprise leadership (Uhl-Bien, 2006). The leader centric view is fundamentally a legacy of the great-man thesis that characterized early leadership research (Terry, 
1995; Van Wart, 2003). This perspective has been widely criticized for romanticizing leaders as heroic figures (Gronn, 2002). Critics regard this body of theory as normative in its perspective, nearly always focusing on ideal behaviorspractices of “great” leaders (Van Wart, 2003). Despite this critique, the notion of leadership as “being in” a specific administrative leader or CEO remains the dominant paradigm. For example, authors have focused on qualities that enable one to enter the fundamental state of leadership (Quinn, 2005), which is “an underlying characteristic of an individual” (Boyatzis, 1982: 21). The result has been an overabundance of studies that focus on the values, qualities and behavioral styles that make for "good" leadership. Some research in public administration has argued that leaders in the public sector are severely constrained from making significant differences (Kaufman, 1981). This conclusion is unsurprising if performance is to be explained by analyzing individual leaders and specific leader behaviorspractices and linking these directly to public sector outcomes. This is not to say that formal leaders do not or should not play a role in bringing about change (Lichtenstein and Plowman, 2009). They have an influence "in and around the system" (Osborn, Hunt and Jauch, 2002: 798) where social interactions and reciprocal influence patterns enable leading-following relationships to develop and evolve over time (DeRue, Nahrgang, Wellman and Humphrey, 2011) and on the relational ways in which stories and narratives are used in leadership practice (Orr and Bennett, in press).

An alternative to a person-centric perspective is to regard leadership as a "social influence process through which emergent coordination (e.g. evolving social order) and change (e.g. new approaches, values, attitudes, behaviorspractices, ideologies) are constructed and produced” (Uhl-Bien, 2006: 668). The acts of leading can take on multiple directions, transcend formal hierarchies and involve multiple actors. From 
this perspective, actors, regardless of hierarchical position can enact practices that are traditionally viewed as leader behaviorspractices or acts of followership. Traditional theories of leadership struggle to sufficiently explain this form of “leading up” or “'leading across”' (DeRue et al., 2011). Leadership, from a complexity perspective, is argued to occur in the "space between” individuals (Lichtenstein, Uhl-Bien, Marion, Seers and Orton, 2007: 5), a “meso” level mechanism (Lichtenstein and Plowman, 2009) that reflects the network of interactions between formal levels. From this perspective leadership is regarded as a social, dynamic, and processual phenomenon (Uhl-Bien, 2006; Uhl-Bien et al., 2007). Relational leadership underpins many of the new approaches emerging in the leadership literature, e.g., collaborative (Raelin, 2006), distributed (Gronn, 2002), shared (Pearce and Conger, 2003), and complexity (Marion and Uhl-Bien, 2001). Relational leadership is a "social influence process through which emergent coordination (i.e., evolving social order) and change (i.e., new values, attitudes, approaches, behaviorspractices, ideologies, etc.) are constructed and produced” (Uhl-Bien, 2006, 668). Developing a deeper understanding of leadership processes, not the attributes of leaders, in complex environments is required to explain the processes by which social order is constructed and changed (Hosking and Morley, 1988) and is critical to this study, which seeks to deepen our understanding of how leadership is accomplished in public sector systems.

\section{Theoretical framework}

Complexity leadership theory suggests that formal top-down administrative forces and informal, adaptive emergent practices are entangled within and across people and practices (Uhl-Bien et al., 2007). Administrative leadership (Marion and Uhl-Bien, 2007) emphasizes formalized structures for authority and decision-making, a focus on 
stability and control, internal integration through standardized processes planning and coordination of operations, resource allocation and structuring of tasks (Marion and Uhl-Bien, 2007). The leadership function involves directing, planning and resourcing activities (Uhl Bien et al, 2007), helping followers understand role and task requirements (Bass, 1985), clarifying roles and responsibilities (Osborn and Hunt, 2007), providing answers (Grint 2005) and resolving problems by applying existing know how (Heifetz, 1994) and integrating and embedding innovations into the formal system (Marion and Uhl Bien, 2007).

Adaptive leadership is an informal leadership process that involves generating and advancing novel solutions in the face of adaptive needs of the organization (Heifetz and Laurie, 2001). This leadership function involves fostering experiments, new discoveries and adjustments from numerous places in the organization or community (Marion and Uhl Bien, 2007), injecting ideas and information so that plans, processes and routines are adapted to changing conditions and setbacks (Dougherty and Hardy, 1996). Creative problem solving requires multiple viewpoints, voices and the encouragement of divergent skills and perspectives (Heifetz and Laurie, 2001). Leadership can create the context for innovative ideas and new ways of working to flourish. Innovative responses to complex problems can trigger further change and “higher-order responses” (Uhl-Bien et al., 2007: 303). Adaptation can be emergent, unpredictable and unexplainable (Marion and Uhl-Bien, 2001) and can be generated through struggles among agents and groups or by the clash of existing but (seemingly) incompatible needs, ideas, or preferences (Fligstein and McAdam, 2012).

Enabling leadership serves to cope with the coordination rhythms, or oscillations, between top-down, hierarchical dynamics and emergent complex adaptive systems 
(Uhl-Bien and Marion 2009). An overemphasis on administrative leadership in complex and volatile environments could deprive an organization of much needed adaptive capacity (Uhl-Bien, Marion and McKelvey, 2007). Our reading of the literature reveals four core tensions addressed by the means of enabling leadership. First, adaptation and change can lead to chaotic collective action and "sustained periods of stress” (Heifetz, 1994: 35). Yet, in other situations enabling leadership may also include injecting adaptive tension to help motivate and coordinate the interactive dynamic (Uhl Bien, 209). Second, leadership in certain environments is required to help actors make sense out of what is happening and give meaning to unfolding events (Plowman and Silansky et al., 2007). From this perspective, actors do not create change, rather they catalyze its development by giving meaning to actions that might otherwise go unnoticed” (Marion and Uhl-Bien, 2001, p. 398). However, in other contexts leaders are involved in sense-breaking (Weick, 1996) to disrupt existing patterns and unfreeze entrenched assumptions (Plowman and Silansky et al., 2007) and disrupting existing patterns by surfacing conflict, creating controversy and fostering discomfort (Lichtenstein and Plowman, 2009). Third, enabling leadership can be required to connect "otherwise disjointed groups" (Schreiber and Carley, 2006 p. 136) and formalise networks to give them legitimacy. However, in other situations adaptation requires mutual adjustment (Mintzberg, 1993), heedful interrelating (Roberts and Weick, 1993) and other processes of informal communication between people conducting interdependent work. Fourth, enabling leadership sometimes involves actively removing, excluding or alienating certain actors and yet in other situations leadership is required to protect dissident voices (Heifetz and Laurie, 2001) and facilitate collective action by protecting actors from external politics and top down directives (Marion and Uhl-Bien, 2001). We 
argue that these four aspects of enabling leadership are held in tension and can shift collective action towards either adaptive or administrative functions. For example, reducing conflict and tension is considered a practice that shifts the balance towards administrative leadership, while injecting tension and conflict shifts the balance the other way - toward adaption and change. These are represented by the arrows in our theoretical framework summarized in Figure 1.

[Figure 1 here]

Our theoretical model raises two critical questions. First, what is the relationship between environmental complexity and the balance of administrative, adaptive and enabling leadership? Second, how does enabling leadership help manage the entanglement (Uhl-Bien et al., 2007) of formal top-down, administrative forces and informal, adaptive emergent forces? To investigate these questions this study provides an in-depth analysis of six urban regeneration initiatives.

\section{Research approach - examining complex case data for leadership practices}

Regeneration projects are chosen because they involve multiple actors and decisions, vary in terms of diversity and duration, and thereby allow an examination of the unfolding of leadership practices under different levels of complexity (Barzelay and Füchtner, 2003). Roden Street involves the regeneration of a small street in south Belfast. This project was a small 'pilot' nested within a much larger regeneration project, in the Greater Village Area of Belfast: a well-known Loyalist area with a long 
history of paramilitary activity throughout the Northern Ireland troubles (Shirlow, 2003).

Ballymun was developed in the mid-1960s. It was Ireland's first, and last, high-rise social housing project. Built on the outskirts of the city and near the airport, it was a symbol of progress in Irish urban planning and development and was designed to address the serious shortage of urban housing at that time.

The Clonard area of West Belfast was targeted for redevelopment by the Northern Ireland Housing Executive (NIHE) after the publication of the first Making Belfast Work (MBW) strategy in 1988 as it had long been an area of significant economic and social deprivation as well as civil unrest. The targeted area consisted of 650 'kitchen' or 'parlor' houses - terraced houses with two rooms on each of two floors. The area was and continues to be largely Catholic and Nationalist, with a tight-knit community and strong voluntary and community organizations.

The Fatima Mansions project is located in the southwest section of Dublin City, relatively near to the city center, consisting mainly of local authority constructed and managed flats. While the location is prime in terms of access to city-based amenities, jobs and transport systems, the area has a reputation for crime, drug-dealing and other anti-social behavior that is one of the worst in the country. Originally consisting of 363 flats and 11 acres, Fatima Mansions represents a medium-sized project in Dublin and, at the end of 2004, the project to regenerate the area was just getting underway, with about $1 / 3^{\text {rd }}$ of the original fourteen apartment blocks demolished, residents moved out and the redevelopment plan approved and project managers in place.

The Hardwicke Street project encompassed the regeneration of 11 blocks and 210 flats in Dublin's Northside and was managed directly by the local authority. There 
were a minimal number and range of stakeholders involved, namely the local authority, the residents and the construction company who won the tender. The total time required from the start of the project (1999) to its conclusion (2005) was relatively short.

The Connswater project is located within the 'Island' local Government electoral ward of East Belfast, close to the Harland and Woolf shipyard and the new 'Titanic quarter'. This had a population of about 1800 people. The project began to gather momentum in 1998 with rumors of redevelopment with a vesting order issued in January 2000. In socio-economic terms, Inner East Belfast (including the Island ward) has consistently been identified as having some of the worst levels of poverty and deprivation in Northern Ireland. The 2005 Noble Report on deprivation and disadvantage placed the constituency as the fifth worst performing of the eighteen parliamentary constituencies in Northern Ireland.

We classify the six urban regeneration projects in terms of levels of complexity (high, medium and low, See Table 1). More detailed descriptions of the regeneration projects can be found in the online supplement that accompanies this article (Endnote 1). In classifying the cases we considered both diversity, in terms of range of features, and duration of the projects. Page (2011) argues that diversity is a fundamental feature of complexity and defines three different categories: within type, across types and community composition (Endnote 2). The cases in this study were selected with a view to capturing situations in which decision-makers were faced with varying levels of diversity, e.g., different stages in the project lifecycle (beginning, middle, end), different types of agents having significant input into decisions (public sector led vs. a broad mix of participants), and the size of the projects (in terms of 
numbers of dwellings involved). In Table 1, we illustrate the outworking of these elements under the column heading 'Diversity'.

Time and its impact on public management has long been recognized as an important but often underappreciated feature of the field (Gulick, 1987; Pollitt, 2008). Haynes (2003) claims "chaos and complexity and their definitions are linked profoundly to time” (p. 32), and goes on to say that in an environment of rapidly changing technological, social and/or policy elements, the longer the duration of a public management project, the greater the complexity and risk of failure. The time dimension of each project is described under the column heading 'Duration' in Table 1.

\section{[Table 1 here]}

\section{Data collection and analysis}

Data were collected on the processes, factors and outcomes (Eisenhardt, 1989, Barzelay and Füchtner, 2003) of decision-making in the six cases based on 32 semistructured interviews with the key actors involved in the urban regeneration projects along with an analysis of secondary sources. Urban regeneration projects are potentially controversial with sensitive outcomes making access to informants and other information problematic. The researchers therefore needed to engage with a small number of key practitioners to broker access into seemingly inaccessible research settings (Van de Ven 2007, p. 50). A snowballing or 'chain referral 'sampling technique was then employed by the researchers to identify potential informants. The method is "well suited for a number of research purposes and is particularly applicable when the focus of study is on a sensitive issue, possibly concerning a relatively private matter, and thus requires the knowledge of insiders to 
locate people for study.” (Biernacki and Waldorf 1981: 141). After interviewing the initial informants, the researcher asked for assistance from the interviewees to help identify other key people involved in the urban regeneration projects. This type of sampling technique works like chain referral and is appropriate when cases are rare or data collection limited to a very small subgroup of the population. Chain referral continued until new interviewees added little to the understanding of leadership in urban regeneration.

All interviews lasted around 90 minutes. Many informants were interviewed more than once. All researchers used a consistent interview guide comprised of five sections: 1) review of factual information about the project; 2) description of their organization, 3) key issues and strategic decisions, 4) objectives and key events and 5) future changes / challenges. At the end of the interview, informants were invited to share any additional information they felt was relevant. Interviews were sent back to interviewees for their review and commentary. Over half of all interviewees provided feedback, including corrections and further explanations.

In developing the case write-up, the interview data was supplemented with document analysis. Source material included community consultation documents, political engagement in planning processes, funding applications in relation to social capacity building, reports in national and local media, and website data from the various community, statutory and private sector organizations involved. These were large, public, consultative and sometimes controversial urban development processes and such generated a great deal of information, both in print, online and through minutes / records of meetings and discussions within and between resident's groups and statutory agencies. 
Analysis of the interviews and secondary data involved a number of steps. The original cases were written up by three different researchers and key project decisions were identified within each case. Cases and the data used were then reviewed by the research team to improve consistency between researchers in relation to the identification of decision-points. Following the review of the complexity leadership literature, an initial list of leadership practices was drawn up and the cases and the interviews were then reanalyzed to extract the range of administrative, adaptive and enabling leadership practices that could be observed at key decision points.

We reviewed each case write-up and interview transcript section-by-section and identified segments of text to populate a leadership practices data-extraction table. The leadership practices were amended as the analysis developed and we were open to the possibility of adding new processes not identified in the original literature review. This enabled us to identify leadership practices in each of the key decision points in the six cases of urban regeneration. Three researchers were individually responsible for coding the data and an independent researcher, not involved in the original data collection, reviewed and discussed the analysis with the original coders until consensus was reached on how to classify instances of leadership within each of the categories (adaptive, administrative and enabling). The final step involved comparing, contrasting and synthesizing the codes in the data extraction table, whilst also returning to the original case write ups, interviews and to the secondary data (document analysis) to ensure that interpretation of events and processes were accurate and that our analysis still reflected the contextual sensitivities of each case. Reviewing and discussing the coding choices while returning to the literature on complexity leadership also strengthened the coding process. Some codes of similar meaning were merged and renamed to reflect the key leadership practices identified in 
the six cases of urban regeneration. When completed, the data extraction table was far too large to be included in the article. An example of the coding approach is provided in Appendix 1. A quantitative summary of the findings is included in Figure 2. 


\section{Findings}

In the low complexity cases (Connswater and Hardwick Street) administrative leadership practices, such as directing, planning and resourcing activities, creating clear lines of authority and integrating innovation into the formal system, were particularly prevalent. The majority of observed practices in these two cases were in the administrative category, but that did not mean that there were no adaptive practices observed. However, adaptive practices appeared in few of the key decision points and were 'wrapped around' with enabling practices - possibly to ensure that uncertainty or diverse views did not derail progress. In low complexity environments, the adaptive practices were few and far between and appeared during decision points that introduced new actors into the system whose input was considered and then integrated into the otherwise linear planning and implementation processes.

In the medium complexity cases (Clonard and Fatima Mansions), administrative leadership practices are still present - perhaps to ensure that activities remain consistent with strategy and mission. Actively supporting the inclusion of diverse skills / perspectives (including boundary-spanning), appear to be particularly important in these cases, as well as in the high complexity cases. In the Clonard case, changing plans, processes, routines in response to tensions, also appeared a number of times. In fact, this particular practice appeared most often in the Clonard case, which was characterized by several major changes during the implementation phase.

Adaptive practices were observed to the greatest extent in the most complex cases and remained constant and indeed dominant throughout the life cycle of the Roden Street/GVA case. In both cases, the adaptive practices outnumbered the administrative practices, while in the Ballymun case the enabling practices were even 
more prevalent than the adaptive practices. Again, the practice of actively supporting the inclusion of diverse skills / perspectives (including boundary-spanning), dominated in these cases, but the other two adaptive practices: stimulating innovative ideas and changing plans, processes, routines in response to tensions, also featured more than in the medium and low complexity cases. This is consistent with the view that leadership can create the context for innovative ideas and new ways of working to flourish and innovative responses to complex problems.

The adaptive practices appear in each of the five decisions for Roden Street and in three out of the five decisions in the Ballymun case, while in the low complexity cases these practices appear infrequently. Even more striking is the fact that in every key decision identified in the two most complex cases, there are one or more observations of enabling practices. In the next section we explain discuss these leadership practices in more detail, with a specific focus on the role of enabling leadership in managing the entanglement of adaptive and administrative practices.

\section{Enabling leadership within the cases}

As noted above, enabling leadership contributes to the ongoing balancing between adaptive and administrative practices by managing four core tensions, these are explained below.

\section{Buffering tension, acting to reduce conflict and injecting tension and conflict}

The first tension involves the interplay between buffering tension, acting to reduce conflict and injecting tension and conflict. Skepticism, resistance and multiple divergent perspectives characterized all of the cases as some point in their development. Interestingly, we observed twice the number of buffering/reducing 
practices across our six cases than we did injecting of conflict and tension, with the Roden St./GVA project being particularly skewed toward this. Indeed, one of the interviewees viewed the Roden St. project overall as an act of enabling leadership in relation to the wider redevelopment of the Greater Village Area - the ultimate aim of the regeneration initiative was "gaining a foothold in the area" (Interview notes). Individuals often played key roles in resolving differences and finding solutions to problems. In Hardwicke Street, a low complexity case, early attempts were made to engage with the community early in the process to mitigate potential issue and deal with problems that threatened to derail the regeneration project. The estate manager acted like a buffer between the tenants and those involved in the regeneration process. He was referred to as a 'troubleshooter' managing concerns before they became a development block.

There was significant concern too in Clonard regarding the inclusion of a new housing provider in the process. Worries over high rents, lack of consultation, lack of awareness of new personnel shifted the project into a period of uncertainty. This in turn instigated a period of confidence building on behalf of Oaklee with residents. This was managed through a conscious effort of reduce tension and local concerns. As the local Oaklee representative stated 'I was there at Clonard every Friday for about two years. It allowed me to get to know the people to be rehoused'. A similar activity emerged in the medium complexity case of Fatima Mansions, with the joint working group continuing to meet through the lifetime of the project to deal with any unanticipated outcomes, and to receive and pass along feedback from residents. 
The corresponding practice of injecting tension and conflict was also observed. In Clonard, tension was raised after the visit of a Minister to the area during which he questioned the plans to knock down a historic building. This resulted in a change to those plans (adaptive practice) and ultimately a re-phasing of the project to build sheltered housing first. The NIHE then began to buffer conflict to keep the development inching forward - and this is particularly reflected in the initiation and resourcing of a community housing development role locally, and the engagement of a number of actors to secure this. In the case of Ballymun, we saw an injecting of tension through the Citizens' Jury exercise, along with an effort at buffering saying that they felt it was worthwhile being optimistic about the future of Ballymun. The Jury pointed out that change could not happen without a vision for the future - an implicit challenge.

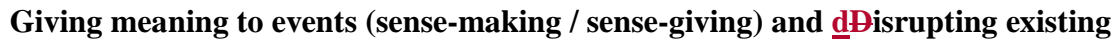 patterns and assumptions}

The second of our tensions is the relationship between giving meaning to events (sense-making / sense-giving) and disrupting existing patterns and assumptions. This tension contains more of a cognitive disruption or buffering achieved through either questioning people's assumptions or clarifying the meaning of aspects of the project. This pair of practices was by far the most prevalent set observed in our cases with 22 observations, equally split between sense-making interventions and disrupting assumptions interventions. However, it is again in the Roden St./GVA project in which the balance between practices on two aspects of the tension is skewed towards 
the one that indicates a shift towards administrative leadership. In the Ballymun project, the instances of these practices are evenly split as is the case in Clonard.

In the medium and high complexity contexts the residents associations became symbols and catalysts for actions by directing attention to what was important for stakeholders. The residents associations also engaged in efforts at sense-making (Weick, Sutcliffe and Obstfeld, 2005) helping to crystallize for occupants the importance of the changes that were occurring, even if it was unclear exactly where the changes would lead. As the changes emerged, the leaders began to see new possibilities for the regeneration projects. Actors, such as the Chairman of the residents association in Clonard became a "tag” (Uhl-Bien and Marion, 2009) by being a focal point for the community, directing attention to critical issues, and being recognized as the spokesman for the area's citizens. There were significant efforts at sense making around the changing identity of Clonard itself, (the name is a Gaelic word for a pasture or meadow). The identification of a new second site close by (through a government decision setting aside traditional regeneration mechanisms and making the land available), allowed for a sensitive decanting of residents who were determined to stay in the same area. The District manager of NIHE reflected about this decision 'The government release of the Mackies site was crucial'. A naming competition, run through the local newspaper, resulted agreement on Cluain Mor - the great pasture, connecting both the original and new communities.

The enabling leadership practice of disrupting existing patterns and assumptions can be seen within high complexity Ballymun process. By ensuring that the Ballymun Citizen's Jury looked afresh at key aspects of anti-community behavior, and sought 
and received advice from the widest possible range of actors - including those internationally, a dialogue was enabled to ensure that all questions were answered, and that progress could be made.

Similarly, in the high complexity case of Roden Street, the initiation of the project itself relied on a disruption of traditional arguments, following multiple (unsuccessful) efforts at giving meaning to events. Recalling these early days, one interviewee commented, 'We had numerous meetings that were a waste of time. It was clear that we needed an honest broker. In 1998 we brought in Mediation Network. The local MP came - the Rev Martin Smyth. Everyone was fighting amongst each other - he told them to get themselves together'. This did not in itself resolve issues, but it did 'out' real and deeply felt concerns reflected by another interviewee 'There was a real fear - that this was an underhand way of further denuding the protestant inner city population' (NIHE interviewee). The disruption of existing patterns created a counterforce to inertia, but subsequent sense making around possible futures dampened down real fears. In Roden Street enabling activity involved leveraging social and political dynamics to stimulate or resist change. Social and political pressures imposed by the context were converted to an advantage. All of the NI cases were embedded in a 'wicked' (Rittel and Webber, 1973) social and political environment shaped by the Northern Ireland ‘troubles’ (Endnote 5). This was also enabled as a change lever. For example, the initial engagement of Clonard Monastery as a host for early residents' meetings in Clonard was symbolic as the Monastery was a community venue and was best known for having been previously used for the initial talks between John Hume and Gerry Adams that lead to the IRA ceasefire and eventually the Good Friday Agreement of 1998. The actors who initiated the residents meetings were not the leaders of the various housing associations and they 
acted from no official role or authority when they started. In Roden Street, the broader political environment was used as a generative push towards regeneration of a traditionally loyalist community in the ethno religious territoriality of Northern Ireland.

Within the medium complexity case of Fatima Mansions we also see these types of enabling practices come to the fore at specific junctures in the developmental process. The first of these was the localization of Dublin local authority offices, which changed the access of residents to their estate managers. The second was the introduction of a public -private partnership approach that acknowledged the need to move the project forward quickly. The Minister (Noel Ahern TD) commented at the time 'I supported the City Council on choosing the PPP approach for Fatima Mansions as I believe that the PPP option has the potential to deliver the regeneration on a faster period than would be the case using the traditional procurement method'.

In the low complexity cases, it is interesting to note that Hardwicke St. had the majority of its enabling practices occur in this set of practices, while Connswater had no examples of these practices.

\section{Coordinating and formalizing networks and ffFacilitating and enabling informal networks}

Our third enabling leadership tension - Coordinating and formalizing networks vs Facilitating and enabling informal networks, was observed more often in the Northern Ireland (NI) cases than in the Republic of Ireland (ROI) cases with seven instances in NI compared to only two in ROI. For example, in Roden Street the creation of 
'community sustainability officer' post early in the process invigorated the community stakeholders, coordinated efforts and allowed for the introduction of alternative plans for the area. It coordinated and formalized a valuable function, without which the project, already complex and controversial may have stalled badly. The Greater Village Regeneration Trust (GVRT) also helped to bring people to an agreement. Actors from across the stakeholder groups induced interactions, enhanced communication and acted as boundary spanners. We also observed radical transformation, which emerged from the interactions of a few people within the regeneration projects. For example, in Clonard the NIHE supported the residents' association, a self-organizing group, to operate without interference from formal authorities. The emergence of the residents' association facilitated interactions and initiatives and increased the amount of resources leveraged. For example, towards the end of the regeneration project the Clonard Residents Association had evolved from an ad hoc network (adaptive structure) to a professionalized association with staff and premises (administrative structure), which allowed them to leverage resources. The central enabling process facilitated this transition. As one of the interviewee's commented, 'We had to build up relationships and be guided by the implementation plan. Formal networks were vital. A lot of initiatives just failed. Informal ones were also extremely important'. In the low complexity case of Connswater, we see that local residents association emerging for the first time, and facilitated by some small funding from the charity sector, begin to engage strategically the development of the community.

In Northern Ireland, there was no cross-project pattern of balance between the two aspects of the tension, although unusually Roden St did exhibit balance between the two while the other NI projects were more skewed (Clonard towards Administrative 
and Connswater towards Adaptive leadership). In the Republic of Ireland, however, both observations in this practice tension emphasized formalising networks - one in Fatima Mansions and one in Ballymun. In Fatima Mansions, the Fatima Regeneration Board was established early on in the project. It brought together an independent Chair (a former Chair of the Labour Court) and representatives from community groups, politicians and local authority to discuss the ongoing regeneration proposals and progress. In Ballymun, the Board of the managing company (Ballymun Regeneration Ltd - BRL) was broadly based with representation from Dublin City Council, other statutory agencies, the commercial sector and representatives from the local community. The main objectives of BRL were to plan and implement the regeneration project, to create sustainable development and build consensus among key stakeholders.

\section{Removing, excluding or alienating dissenting actors and protecting actors from external politics and top-down directives}

Our last leadership tension 'Removing, excluding or alienating dissenting actors vs Protecting actors from external politics and top-down directives' illustrates aptly the role of enabling leadership in protecting what are essentially creative processes from inhibiting forces such as policy makers, other administrators or environmental pressures (Mumford, Scott, Gaddis and Strange, 2002). Such leadership was required to protect actors from external politics and top-down directives and preventing administrative leaders from stifling or suppressing beneficial innovation and adaptation (Uhl-Bien, Marion and McKelvey, 2007). Interestingly, the literature is less forthcoming on the opposite aspect of the tension, which involves removing or 
excluding actors that do not agree and are a barrier to progressing the project. This set of practices was the least observed across the six cases, but still was observed at least once in all but one of the cases.

For example, in the medium complexity case of Clonard, the role played by the initial Chair of the resident's association (who was himself a former builder) was seen as very significant in the early of the process. His tacit knowledge and community position enabled the residents to made real and significant interventions at an early stage. As one resident involved in this process commented 'The chairperson...- he used to be a builder. That was very good, he knew what he was doing. They couldn't just tell him anything'.

We see a similar process in Fatima Mansions - our other medium complexity example. The early 'Corcoran report' (1998) detailed a tenants survey, which in turn documented and reinforced many of the issues that had been identified as social problems for many years and became incorporated into a national research report on social housing in Ireland. The negative conclusions of the research gave empirical data and a strong argument for community groups to use in pressing for change (see Corcoran and Fahey 1999), and effectively acted as institutional acknowledgement of concerns as the project progressed.

In one of our low complexity cases (Connswater), we see the initial exclusion of actors in an attempt to move the development more quickly than was reasonable. The lack of a functioning community group at this early stage meant that information about development plans was never fully communicated causing one resident to 
protest 'The first thing we knew about it was when leaflets were put through letterboxes. Even local politicians knew nothing about it'.

Perhaps the most vivid examples of this leadership tension is within the high complexity cases, where significant external political forces were being exerted on the projects. In Roden Street, the significant resourcing of GVRT as a community resource, allowed it to operate as a strategic boundary spanner and not get dragged into local community difficulties, which would have further stalled the project. However, within all of the projects there was little acknowledgement of exclusion as a tactic (even though it undoubtedly occurred) and much awareness of inclusive behaviorspractices. This may be reflective of the cases or more likely the reluctance of respondents to focus on the messy political micro processes which occur within complex organizational and community structures.

\section{Discussion: the duality of enabling leadership}

This article began by contesting the traditional, person-centric and hierarchical notions of leadership, underpinning much research in the public administration discipline and argued that the field might be enhanced by considering the social interactions and reciprocal influence patterns that enable leading-following relationships to develop and evolve over time (DeRue et al., 2011). Drawing on the emerging field of complexity leadership we argue that leadership emerges through dynamic interactions (Bradbury and Lichtenstein, 2000) when individuals as well as groups respond to both external pressures and conflicting constraints (Lichtenstein et al., 2006). 
The six urban regeneration projects offered a unique and rich opportunity to examine complexity leadership in differentiated public sector settings. As such, the study contributes rare empirical examples to the field of complexity leadership, which, thus far, has been largely conceptual (Lichtenstein and Plowman, 2009). We addressed our first research question by examining instances of adaptive, administrative and enabling practices in urban regeneration projects with varying degrees of complexity. Whilst our data suggests that the nature of leadership does vary by levels of environmental complexity (Figure 2), we are cautious about the claims that we can make from this aspect of our exploratory study. In particular, we recognize the limitations of evaluating complexity by only time and diversity and also translating qualitative data on reported instances of leadership practices into numerical counts. However, this exploratory work does reveal patterns. The data suggest that administrative practices are more prevalent in the low complexity urban regeneration projects and adaptive practices are more prevalent as complexity increases. Further empirical analysis, based on our coding framework and involving larger samples and quantitative methods, would be fruitful direction for future research.

To address our second research question we examined the tensions inherent in enabling leadership. Our initial conceptual model (Figure 1) positioned these tensions as dualisms e.g. Buffering tension, acting to reduce conflict v.s injecting tension and conflict. These tensions are often seen as dualisms because we "accentuate contradictions by interpreting data through simple, bipolar concepts, constructing logical, internally consistent sets of abstractions that separate opposites” (Lewis and Smith, 2012, p. 762). The literature frequently resorts to dualisms when considering leadership. The literature is abundant with contingency theories portraying leaders as most effective when they adapt to some aspect of their environment (e.g., Fiedler, 
1971). Our study suggests that it is may be erroneous to separate leadership practices into two opposed paired elements, (e.g. adaptive or. administrative).

\section{Gonclusions}

Our study shows that the challenges encountered in urban regeneration projects rarely occur in isolation so collectives often deal with multiple interconnected issues and challenges. Thus, in complex environments, these apparently competing practices may be occurring concurrently. Enabling leadership is required to both maintain a sense of stability in order to coordinate, structure and control organizational activity (administrative) as well as generate the conditions for innovation, change and transformation (adaptation) (Selznick, 1949; Uhl-Bien, Marion and McKelvey, 2007). Therefore, these tensions may better be regarded as dualisms, rather than dualities (Farjoun 2010). When constructed not as dualism but as duality the idea of two essential elements is retained but they are viewed as interdependent (Farjoun, 2010). Seen as dualities the twin functions of leadership are both contradictory and complementary. These elements are mutually enabling and a constituent of one another. Thus, administrative leadership creates the structures that both enable as well as constrain the adaptive actions of individuals and collectives (Giddens, 1984). Similarly, people's adaptive practices reinforce and reproduce a set of beliefs, norms and roles that create expectations that shape future performances of the action (Callon and Latour, 1981).

\section{Conclusions}


Conceptualizing This insight In highlighting the tensions between administrative and * adaptive practices and conceptualizing them as dualisms, rather than dualities (Farjoun 2010), this study -has implications for leadership theory, practice and development and practice. Future research into theoretical constructs could examine further the complex, nonlinear dynamics of leadership. As with this study, qualitative approaches may be best placed to reveal and investigate interwoven tensions (Smith and Lewis, 2011) and depict the dynamic and mutually constitutive relationship between (Jarzabkowski, 2008) adaptive and administrative functions. Qualitative comparative analysis (QCA) may build upon our exploratory work by examining the conjuncture of variables and their inter-relationships and how these affect outcomes (Fiss, 2007; Ragin, 1987). Comparing the findings of this study, especially in relation to enabling behaviorspractices, to those proposed by Hazy and Uhl-Bien (2015) in relation to the 'community-building, information gathering and information using' leadership practices, will be an important next step in theory development. Building on the case research identified-offered in this study, above and extendinged this analysis and comparing the findings to cases drawn from other eases-settings and other sectors is an obvious next step, to observe how findings compare and extend the malysis across sectors.

In terms of leadership practice, our study suggests that greater attention needs to be paid to the tensions inherent in enabling leadership if actors are to cope with the eomplex, collaborative, cross-boundary, aldaptive work in which they ane inereasingly engaged. Aceptance of and engagement with these tensions, may help actors to live and thmive with pressures (Smith and Lewis, 2011) and ean motivate a search for new pessibilities (Festinger, 1957). Day (2000; et al., 2014) argues that most leadership development is currently leader development, often driven by competency
Formatted: Level 1, Space Before: $0 \mathrm{pt}$, After: $0 \mathrm{pt}$, Widow/Orphan control, Adjust space between Latin and Asian text, Adjust space between Asian text and numbers 
frameworks, focused on the styles, actions, and competencies of the individuals who have been formally assigned leadership roles or have potential to become leaders. Bolden and Gosling (2006, p. 147) argue that competencies do not provide “a sufficiently rich vocabulary” for the complex, diverse, and connected nature of leadership (2006, p. 158). Nevertheless,-Seidle, B., Fernandez, S. and Perry, J. L. (2016) present contrary evidence, which suggests well-designed leadership programs, incorporating a focus on the individual, their relationships and situational context and complexity, can assist in the development of positive leadership outcomes. Leadership development can also involve shaping the reasoning and affording opportunities to actors to generate activities aimed at resolving the prevailing challenges faced by the collective, while exploring synergistic opportunities for coping with enduring tensions.

In terms of leadership practice, our study suggests From this perspective-a core function of leadership development could be-is to embrace leadership tensions and help shift actors beyond “either/or” toward “both/and” behaviors. This “paradoxical thinking that entails a both/and mind-set that is holistic and dynamic”- (Lewis and Smith, 2012). In terms of leadership practice, our study suggests Acceptance of and engagement with leadership tensions can help actors to live and thrive with pressures (Smith and Lewis, 2011) and can motivate a search for new possibilities (Festinger, 1957). that Ggreater attention needs to be paid to the tensions inherent in enabling leadership if actors are to cope with the complex, collaborative, cross-boundary, adaptive work in which they are increasingly engaged. Acceptance of and engagement with these tensions, may help actors to live and thrive with pressures (Smith and Lewis, 2011) and can motivate a search for new possibilities (Festinger, 1957). Eeadership development also involve shaping the reasoning and affording 


\section{Endnotes}

1. The supplement is drawn from previously published case descriptions that may also be found in Rhodes, M. L., J. Murphy, J. Muir and J. A. Murray (2010). Public Management and Complexity Theory: Richer Decision-Making in Public Services, Taylor \& Francis.

2. 'Community composition' is a variable that captures the differences between populations of a community.

3. In the case of Roden Street/Greater Village, the project to regenerate Roden Street itself was relatively contained - consisting of 26 new dwellings and taking three years in planning and four years' implementation. For this reason it had originally been considered to be the least complex project in Northern Ireland, However, Roden St. was a only small subset of the larger project to regenerate the entire Greater Village Area (consisting of 1500 new dwellings) which had begun in the 1990s and was still in the planning stages in the mid 2000s.

4. Northern Ireland Statistics and Research Agency (2005), Northern Ireland Multiple Deprivation Measure, http://www.nisra.gov.uk/deprivation/archive/NIMDM2005FullReport.pdf 
5. 'The troubles' is a colloquial phrase used to denote the period of political violence in NI from the late 1960's to the IRA and loyalist ceasefires of the early 1990’s. 


\section{References}

Barzelay, Michael and Natascha Füchtner. 2003. Explaining public management policy change: Germany in comparative perspective, Journal of Comparative Policy Analysis, 5(1): 7-27. ISSN 1387-6988

Bass, Bernard. M. 1985. Leadership and performance beyond expectations. New York: Free Press.

Biernacki Patrick and Dan Waldorf. 1981. Snowball sampling: problem and techniques of chain referral sampling. Sociological Methods and Research. 10, 2, 141-163.

Boin, Arjen, R. and Marc Otten, H.P. 1996. Beyond the Crisis Window for Reform: Some Ramifications for Implementation, Journal of Contingencies and Crisis Management, 4: 149-161. doi: 10.1111/j.1468-5973.1996.tb00087.x

Boyatzis, Richard, E. 1982. The competent manager: a model for effective performance. London: Wiley.

Bradbury, Hilary, and Lichtenstein, Benyamin, M.B. 2000. Relationality in organizational research: Exploring the space between, Organization Science, 11: 551564.

Callon, Michel and Bruno Latour. 1981. Unscrewing the Big Leviathan: How Actors Macro- Structure Reality and How Sociologists Help Them To Do So, in K. Knorr Cetina and A.V. Cicourel (eds) Advances in Social Theory and Methodology: Toward an Integration of Micro- and Macro-Sociologies, pp. 277-303. London: Routledge \& Kegan Paul. 
Derue, D. Scott., Jennifer.D. Nahrgang, Ned Wellman, and Stephen. E. Humphrey.

2011. Trait and Behavioral Theories of Leadership: An Integration and Meta-

Analytic Test of Their Relative Validity, Personnel Psychology, 64: 7-52.

doi: 10.1111/j.1744-6570.2010.01201.x

Dougherty, Deborah, and Cynthia Hardy. 1996. Sustained product innovation in large, mature organizations: Overcoming innovation-to organization problems, Academy of Management Journal 39: 1120-1150.

Eisenhardt, Kathleen. M. 1989. Building theories from case study research, Academy of Management Review, 14: 532-550.

Farjoun, Moshe. 2010. Beyond dualism: Stability and change as a duality, Academy of Management Review, 35: 202-225.

Fernandez, Sergio. 2005. Developing and testing an integrative framework of public sector leadership: Evidence from the public education arena, Journal of Public Administration Research and Theory, 15: 197-217.

Fernandez Sergio, Yoon, Jilk Cho and James L. Perry. 2010. Exploring the link between integrated leadership and public sector performance. Leadership Quarterly, 21(2):308-323.

Fiedler, Fred. E. 1958. Leader attitudes and group effectiveness. Urbana: University of Illinois Press

Fligstein, Neil, and Doug McAdam. 2012. A theory of fields, Oxford University Press. Giddens, Anthony. 1984. The Constitution of Society. Polity Press: Cambridge, U.K. Strat. 
Grint, Keith. 2005. Problems, problems, problems: The social construction of 'leadership’, Human Relations, 58: 1467-1494.

Grint, Keith. 2007. Learning to Lead: Can Aristotle Help us Find the Road to Wisdom? Leadership, 2(2): 231-246.

Gronn, Peter. 2002. Distributed leadership as a unit of analysis, The Leadership Quarterly, 13: 423-451.

Gulick, Luther. 1987. Time and Public Administration, Public Administration Review, 47(1): 115-120.

Hansen, Jesper. R. and Anders, R Villadsen, 2010. Comparing Public and Private Managers' Leadership Styles: Understanding the Role of Job Context, International Public Management Journal, 13(3): 247-274.

Hansen, Kathrene. 2013. Commentary: From Theory to Practice-The Federal Executive Board: Leadership in Action, Public Administration Review, 73: 565-566.

Haynes, Philip. 2003. Managing Complexity in the Public Services. Berkshire, UK: Open University Press.

Hazy, Jim. and Mary Uhl-Bien. 2015. Towards operationalizing complexity leadership: How generative, administrative and community-building leadership practices enact organizational outcomes, Leadership, 11(1): 79-104

Heifetz, Ronald, A. 1994. Leadership without easy answers. Cambridge, Mass, Belknap Press of Harvard University Press. 
Heifetz, Ronald, A. 1998. Walking the fine line of leadership, The Journal for Quality and Participation, 21(1): 8-14

Heifetz, Ronald, A., Marty Linsky, and Alexander Grashow. 2009. The practice of adaptive leadership: Tools and tactics for changing your organization and the world. Cambridge, MA: Harvard Business Press.

Heifetz, Ronald. A. and Donald, L. Laurie. 1999. Mobilizing adaptive work: Beyond visionary leadership. In Conger, J., et al. (Eds.) The leader's change handbook. San Francisco, CA: Jossey-Bass.

Heifetz, R.A. and Donald, L. Laurie. 2001. The work of leadership, Harvard Business Review, 79(11): 131-141.

Hosking, Dian, Marie. and I.E Morley. 1988. The skills of leadership. In Hunt J. G., Baliga R., Dachler P. and Schriesheim C., Emerging Leadership Vistas. Lexington, Mass: Lexington Press.

Howell, Jane. M. and Kathleen Boies. 2004. Champions of technological innovation: The influence of contextual knowledge, role orientation, idea generation, and idea promotion on champion emergence, Leadership Quarterly, 15: 123-143.

Kaufman, Herbert. 1981. Fear of Bureaucracy: A Raging Pandemic, Public Administration Review, 41: 1-9.

Kim, Soonhee. 2002. Participative Management and Job Satisfaction: Lessons for Management Leadership, Public Administration Review, 62: 231-241.

doi: 10.1111/0033-3352.00173 
Lewis, Marianne. W. and Wendy K. Smith. 2014. Paradox as a Metatheoretical Perspective: Sharpening the Focus and Widening the Scope. The Journal of Applied Behavioral Science, 50(2), pp.127-149. Available at: http://jab.sagepub.com/cgi/doi/10.1177/0021886314522322.

Lichtenstein, Benyamin, Mary Uhl-Bien, Russ Marion, Anson Seers, James D. Orton, and Craig Shreiber. 2006. Complexity leadership theory: An interactive perspective on leading in complex adaptive systems. E:CO Emergence: Complexity and Organization, 8(4), pp.2-12.

Lichtenstein, Benyamin, and Donde A. Plowman. 2009. The leadership of emergence: A complex systems leadership theory of emergence at successive organizational levels, The Leadership Quarterly, 20(4): 617-630

Marion, Russ, and Mary Uhl-Bien. 2001. Leadership in complex organizations, The Leadership Quarterly, 12: 389-418.

Marion, Russ, and Mary Uhl-Bien. 2007. Being there even when you are not: Leading through structures, systems, and processes. In Complexity and strategic leadership. Edited by R. Hooijberg, J. Hunt, J. Antonakis, K. Boal, and N. Lane. Elsevier, Amsterdam.

McKelvey, Bill. and Benyamin B. Lichtenstein. 2007. Leadership in Four Stages of Emergence. In Complex Systems Leadership Theory: New Perspectives from Complexity Science on Social and Organizational Effectiveness edited by Jim. K. Hazy, Jeffrey. Goldstein and Benyamin. B. Lichtenstein. Boston, MA: ISCE Publishing Company, pp. 93-107. 
Mintzberg, Henry. 1983. Structure in Fives: Designing Effective Organizations.

Prentice-Hall, New Jersey.

Mumford, Michael. D. and Brian Licuanan. 2004. Leading for innovation:

Conclusions, issues, and directions, The Leadership Quarterly, 15(1): 163-171.

Mumford, Michael. D. Gina Marie Scott, Blaine Gaddis and Jill M. Strange. 2002.

Leading creative people: Orchestrating expertise and relationships, Leadership

Quarterly, (13):705- 750.

Nalbandian, John, Robert O'Neill, J. Michael Wilkes and Amanda Kaufman. 2013.

Contemporary Challenges in Local Government, Public Administration Review, 73(4): 567-574.

O’Gorman, A. 2001. The Miracle of Fatima Housing Ireland Dublin: The housing Unit, Issue 5, March. 2-4

Osborn, Richard, N. and James Hunt. 2007. Leadership and the choice of order: Complexity and hierarchical perspectives near the edge of chaos, The Leadership Quarterly, 18: 319-340.

Osborn, Richard, N., James, G. Hunt, and Lawrence, R. Jauch. 2002. Toward a contextual theory of leadership. The Leadership Quarterly, 13: 797-837.

Page, Scott. 2011. Diversity and Complexity. Princeton, NJ: Princeton University Press.

Pearce, Craig, L. and Jay, A. Conger. 2003. Shared Leadership: Reframing the Hows and Whys of Leadership. Thousand Oaks, CA: Sage 
Pollitt, Christopher. 2008. Time, Policy, Management: Governing with the Past. Oxford: OUP.

Plowman, Donde, A. and Dennis Duchon. 2008. Dispelling the myths about leadership: From cybernetics to emergence. In Complexity leadership edited by Mary Uhl-Bien and Russ Marion (Eds.), Part 1: Conceptual foundations (pp. 129-154). Charlotte, NC: Information Age Publishing.

Plowman, Donde, A. Stephanie Silansky, Tammy Beck, LaKami Baker, Multa Kulkarni and Deandra Travis. 2007. The role of leadership in emergent, selforganization, The Leadership Quarterly, 18: 341-356.

Quinn, Robert, E. 2005. Moments of greatness: Entering the fundamental state of leadership, Harvard Business Review, July-August.

Raelin, Joe. 2006. Does Action Learning Promote Collaborative Leadership? Academy of Management Learning \& Education, 2006, Vol. 5, No. 2, 152-168

Rittel, Horst, and Melvin M. Webber. 1973. Dilemmas in a General Theory of Planning, Policy Sciences, 4: 155-169. Elsevier Scientific Publishing Company, Inc: Amsterdam.

Schreiber, Craig and Kathleen M. Carley. 2006. Leadership style as an enabler of organizational complex functioning, Emergence: Complexity and Organization; 8(4), p61

Selznick, Philip. 1949. TVA and the grass roots; a study in the sociology of formal organization. Berkeley, CA: Univ. of California Press. 
Shirlow, Pete. 2003. Ethno-sectarianism and the reproduction of fear in Belfast, Capital and Class, 27(2): 77-93.

Smith, Wendy. K. and Marianne Lewis. 2011. Toward a theory of paradox: A dynamic equilibrium model of organizing. Academy of Management Review, 36, 381403.

Terry, Larry. D. 1995. Leadership of Public Bureaucracies: The Administrator as Conservator. Thousand Oaks, CA: Sage Publications.

Trottier, Tracey, Montgomery Van Wart and Xiaohu Wang. 2008. Examining the Nature and Significance of Leadership in Government Organizations, Public Administration Review, 68: 319-333. doi: 10.1111/j.1540-6210.2007.00865.x

Uhl-Bien, Mary. 2006. Relational Leadership Theory: Exploring the social processes of leadership and organizing, The Leadership Quarterly, 17(6): 654-676.

Uhl-Bien, Mary. Russ Marion. and Bill McKelvey. 2007. Complexity Leadership Theory: Shifting leadership from the industrial age to the knowledge era, The Leadership Quarterly, 18: 298-318. ISSN: 1048-9843

Uhl-Bien, Mary. and Russ Marion. 2009. Complexity leadership in bureaucratic forms of organizing: A meso model. Leadership Quarterly, 20(4), pp.631-650.

Van Wart, Montgomery. 2003. Public-Sector Leadership Theory: An Assessment, Public Administration Review, 63: 214-228.

Van Wart, Montgomery. 2013. Lessons from Leadership Theory and the Contemporary Challenges of Leaders, Public Administration Review, 73: 553-565. doi: 10.1111/puar.12069 
Weick, Karl. E. 1979. The Social Psychology of Organizing. 2nd ed. Reading, MA:

Addison-Wesley.

Weick, Karl. E., Kathleen M. Sutcliffe and David Obstfeld. 2005. Organizing and the

Process of Sensemaking, Organization Science, 16(4): 409-421.

Weick, Karl, E. and Karlene Roberts. 1993. Collective mind in organizations: Heedful interrelating on flight decks. Administrative Science Quarterly, 38(3), pp.357-381.

Available at: http://www.jstor.org/stable/10.2307/2393372.

Weick, Karl. E. 1995. Sensemaking in Organizations. Thousand Oaks, CA: Sage.

Wheatley, Margaret. 2006. Leadership lessons from the real world, Leader to Leader, 41: 16-20. doi: 10.1002/ltl.185

Wright, Bradley. E. and Sanjay K. Pandey. 2010. Transformational Leadership in the Public Sector: Does Structure Matter?, Journal of Public Administration Research and Theory, 20: 75-89.

Yukl, Gary. 2002. Leadership in Organizations. (5th ed.). Upper Saddle River:

Prentice- Hall

Yukl, Gary. 2005. The leadership in organizations. New Jersey: Pearson Higher Education. 


\section{Supplement - Extended Case Descriptions}

\section{Roden Street/Greater Village Area: High Complexity}

Roden Street is small street in south Belfast that runs perpendicular to the Donegall Road - a large main street that has long been a point of reference in Belfast. This project was a small 'pilot' nested within a much larger regeneration project, in the Greater Village Area of Belfast: a well-known Loyalist area with a long history of paramilitary activity throughout the Northern Ireland troubles (Shirlow, 2003). Overall, the population in the area had been dropping precipitously, many long-time residents moving out of the area and immigrants, students and new employees of the local hospitals moving in (Endnote 1). Nevertheless, in terms of location, Roden Street and the Greater Village Area are considered to be prime real estate.

Initially, the responsible public agency, the Northern Ireland Housing Executive (NIHE), had full capacity for undertaking the regeneration of the area. In 1999, in order to gain some momentum for the redevelopment they proposed the demolition of 111 dwellings (60\% owner occupied, $20 \%$ private rental and $20 \%$ social), within the context of wider development plans for the greater village area, comprising 1,500 dwellings. A shift in funding led to the establishment of the South Belfast Partnership Board (SBPB), which in turn supported the creation of the Greater Village Regeneration Trust (GVRT). The NIHE provided an administrative function, focusing on planning and coordinating operations. The introduction of the South Belfast Partnership Board and the subsequent establishment of the GVRT changed the dynamics of interaction among stakeholders. This was reinforced by the decision to create a 'community sustainability officer' post early in the process which itself fostered interconnectivity, created linkages, invigorated the community stakeholders 
and allowed for the introduction of alternative plans for the area. A GVRT proposed 'Framework plan' for the area moved this process further forward, and engaged the community themselves, statutory and voluntary sector stakeholders and local political representatives. This occurred alongside the formal vesting order for Roden Street itself - the beginning of the wider regeneration initiative.

Two-thirds of the way through the regeneration project (in early 2003), the Fold Housing Association (Fold) was contracted to undertake all social housing development in the area. Fold is a relatively large housing association operating throughout Ireland and had its own resources and influence to balance that of the NIHE. In 2005, a 'sod-turning' ceremony on the Roden Street site was held and construction finally began on the 26 social housing dwellings to be built and managed by Fold.

In the meantime, the NIHE published its draft proposal in 2004 for the redevelopment of the larger Greater Village Area (1,500 dwellings). The GVA proposal included five alternatives for consideration, ranging from a minor rehabilitation program to a '95 per cent demolish/redevelop’ approach estimated to cost $£ 107$ million. However, the Greater Village Regeneration Trust reacted with disappointment to the long-awaited proposal, as it felt that it did not reflect the desires of the community documented in the framework proposal that had been launched in 2002. In response, the GVRT swung into action and produced a sixth alternative which the NIHE agreed to include, with its original five alternatives, in the consultation packs sent out to all residents in the area.

The GVRT influenced the agenda going forward, with a proposal for low cost owneroccupier housing in the wider Roden Street area - requiring NIHE to purchase land 
from the Department of Social Development to facilitate low cost housing. GVRT's involvement continued placing them regularly at the center of a complex decisionmaking along with the NIHE and Fold Housing Association.

\section{Ballymun: High Complexity}

Ballymun is the largest of the three projects in Dublin and, in fact the largest of all of the projects in the study. A lot has been written about this area (Endnote 2) and the many features of the project cannot possibly be addressed in this brief summary. The current regeneration project began in 1997 with the establishment of Ballymun Regeneration Ltd. (BRL), a semi-state company owned jointly by the Department of Finance and Dublin City Council. The thirteen Board members of BRL include two local councilors, the City Architect, Director of Traffic and Managing Director of BRL (all three from Dublin City Council), three community representatives, four representatives from various statutory agencies (including the Secretary of the local University) and an independent chairman appointed by the Dublin City Council. The project is funded through the Area Regeneration Program funding from the Department of the Environment, Heritage and Local Government, various urban renewal schemes and partnerships as well as targeted funding for particular programs such as childcare, health and social supports. Overall the project covers an area of about 1.5 square miles and 5,200 dwellings (of which 2,800 are in flat complexes and 2,400 are houses), with about 20,000 people living in the area.

The 1998 Master Plan proposed an ambitious 10-year regeneration plan encompassing physical, social, economic, environmental, cultural and process elements. Progress under each of these headings is tracked by the Monitoring Committee of the Board and reported every 1-2 years as a requirement of the Urban Renewal Scheme / 
Integrated Area Program. Because of the plethora of objectives, it is difficult to gauge the status of the project as a whole, but in terms of the housing elements, approximately 1200 of the 6000 planned new units were completed as of the end of 2004, with another 1200 on site. Demolition of the 15-storey tower blocks and 8storey ‘slab’ blocks had begun and both the civic center and leisure center on Ballymun’s new 'Main Street' were open for business. Of the planned 6000 new units, the split between social and private is approximately 50/50, with the voluntary sector providing about $10 \%$ of the social housing. The total number of dwellings that are planned for the area as a whole is nearly 10,000, with the social/private split being $40 \% / 60 \%$. This is a huge shift from the pre-project ratio of $80 \%$ social to $20 \%$ private housing and also incorporates a significant increase in housing density.

The 2003-2004 progress report was upbeat about the increasing property values in the area and the attraction of private investment for the first time in decades. Unemployment was down and the number of childcare places was significantly increased with brand new neighborhood facilities supporting crèches, job centers and other community services. With all the good news in the report however, a note of caution was sounded in the conclusion. "The success reported in this document is at a crucial phase and needs commitment and bolstering to maintain momentum and ensure that the huge public investment is supplemented and enhanced by private investment and secured to make a solid framework for the future.” (BRL 2005: 69) This suggests that management of the project is concerned that money (and government interest in the project) is running out. It is difficult to get clarity on the budget figures for a project of this size and complexity, however the housing element of the plan was estimated to cost $€ 332$ million in the Master Plan. The project end date at the time of completing the case study was 2010. 
As we will see in each of the projects studied, there were a number of events and/or reports that led up to and shaped the official 'beginning' of the project. Ballymun in its current form was created in the mid 1960's as Ireland's first (and last) high-rise social housing project. Built on the outskirts of the city, near the airport, Ballymun was a symbol of progress in Irish urban planning and development and was designed address the serious shortage of urban housing at that time. However, "it flew in the face of everything Irish politicians believed about housing” and was "an unrepeated experiment in modernity” (Power 1993) that was widely condemned as a failed estate fairly early on in its history. Problems with construction, a lack of amenities in the area, poor housing management by the local council, economic recession, social change and drug-dealing, and misguided housing policy combined to plummet the community into a black-spot of unemployment, crime, anti-social behavior, vacant dwellings and boarded-up shops. By 1986, turnover in the council housing had reached nearly $50 \%$ and this year was seen as a "year of crisis” in the area (Somerville-Woodward 2002).

The difficulties in the area over the years had a lateral effect of generating significant expertise amongst residents in lobbing, complaining, working together and forging relationships with public and private sector organizations to address festering problems. From broken lifts to bank closings, playgrounds to pools, the residents of Ballymun were nearly always organizing to protest about some crisis in their community. In fact, Somerville-Woodward (2002) suggests that Ballymun became something of a training ground for local activists in the 1980s and the need to engage productively with residents led to Dublin Corporation (Endnote 3) moving the housing management and rent collection functions for the estate to a local office - the 
first decentralization of this function in the state. The first Housing Task Force for an urban estate was set up in Ballymun in 1987 and with a membership comprised of local T.D.s., members of the Ballymun Community Coalition, the Combat Poverty Agency, and officials from Dublin Corporation and the Eastern Health Board. Not only was this an important step in including residents and other community representatives in a key local policy forum, but the agenda included social as well as physical improvements.

One of the first projects undertaken by the Task Force was getting Ballymun to feature on Dublin Corporation's list of estates scheduled for major Remedial Works. From not being on the list in November 1987, the Task Force succeeded in getting a major program proposed in June of 1988 costing between £50-70 million and planned for eleven phases over 10 years. A novel element of the proposed program was the level of community involvement that was to be a feature of all physical/social improvements.

After the first phase of the refurbishment was completed in 1993, the Department of the Environment and Local Government insisted that an evaluation be carried out to see if the project (which had cost double what it had been planned at) was achieving value for money. The resulting report from Craig Gardner / Prices Waterhouse turned out to be a watershed in the history of the area as it included among its five alternatives the clearance and redevelopment of the entire estate. However, the feeling of the community and Dublin Corporation was to go for a more conservative approach and, after a period of discussion, consultation and debate, to choose the 
option of a balance of refurbishment and some demolition of the worst of the tower blocks, replacing these with housing more in keeping with Irish preferences.

However, by 1996, the Celtic Tiger was beginning to roar and the Irish economy was picking up significantly. The rainbow coalition was in power with an aggressive social agenda and the then Minister for the Environment, Brendan Howlin and Minister of State, Liz McManus suggested that, since the cost of refurbishment was extremely high and would need to be redone in another 15 years anyway, why not go for something that would once and for all rectify the mistakes of the past and put Ballymun on the path to a completely new future. The Ballymun Housing Task Force accepted this challenging opportunity with enthusiasm and a new entity was created in 1997 to oversee the design and implementation of a whole new town - Ballymun Regeneration Ltd. (BRL). Dublin Corporation would remain as the landlord of all social housing in the area as well as have the responsibility for those infrastructural elements that were under its remit (e.g., roads, lighting, sewage), but BRL would be responsible for the integrated planning and development of the area. BRL was not as independent from Dublin Corporation or the state as was a predecessor entity, Temple Bar Properties Ltd., which was set up by legislation in 1991 to regenerate a run-down area on the south bank of the Liffey River. While highly successful in terms of economic, cultural and architectural achievements, the Temple Bar project was seen by Dublin Corporation as having largely ignored social and community needs and, in particular, had made little contribution to the housing deficit in the city. It was seen as crucial to ensure that this did not happen in Ballymun. In order to clarify the roles of the various organizations involved, the Ballymun Housing Task Force was reconstituted to be a largely community-based group and was renamed the Ballymun 
Neighborhood Council (BNC). There are seven elected representatives from each of the five neighborhoods in Ballymun that sit on the BNC Board, as well as one representative each from Dublin City Council and BRL. In addition all of the local T.D.s sit on the board of BNC. BNC has the role of coordinating the community consultations with BRL as well as working with Dublin City Council and BRL to ensure that the changing needs of the community are understood and addressed. In 1998, the Ballymun Masterplan was published comprising 31 chapters covering every aspect of the plans for the area: from education to energy, transport to training and education, and economic development to community facilities.

The non-profit housing sector also plays a role in this project, which is not the case in any of the other Republic of Ireland projects studied. Non-profit housing providers were invited by BRL to tender to build housing and to gain sites with the result that approximately 140 d3wellings were complete by 2004, with another 160 dwellings planned. These are a mix of rental accommodation and co-operative ownership and are spread throughout the Ballymun area. In terms of decision-making on the overall project, however, the non-profit sector had virtually no role.

\section{Clonard/Cluain Mór: Medium Complexity}

The Clonard/Cluain Mór project began when the Clonard area of West Belfast was targeted for redevelopment by the Northern Ireland Housing Executive (NIHE) after the publication of the first Making Belfast Work (MBW) strategy in 1988. This area had long been an area of significant economic and social deprivation as well as civil unrest. The targeted area consisted of 650 'kitchen' or 'parlor' houses - terraced houses with two rooms on each of two floors. The area was (and continues to be) 
largely Catholic and Nationalist, with a tight-knit community and strong voluntary and community organizations and at the time prior to regeneration was nearly $100 \%$ owner occupied. Upon hearing rumors of the possible redevelopment, area residents came together to form the Clonard Residents Association (CRA). This was an informal emergent group, rather than an act of authority, comprised of interactive agents engaging in a cooperative effort. The NIHE proposal to demolish 650 dwellings and replace these with 200, necessitating the relocation of many residents, was met with dismay and it was clear to all involved that additional nearby housing would need to be found or built in order to gain community approval.

Throughout 1992 and 1993 the CRA met frequently to discuss plans and to communicate issues, concerns and desires to the NIHE. Negotiations between various government departments got underway to see if a solution could be found to the problem of additional housing, and the adjacent vacant site of the old Mackies metal works factory was identified as a potential housing site. With the promise of approximately 300 new houses to be built on the Mackies site, the vesting order for the Clonard site as originally planned was approved in 1994.

Phase I of the Clonard project got underway in 1995 and then, in 1996, the building program for all social housing was moved from the NIHE to Northern Ireland Federation of Housing Associations. This resulted in the introduction of a new player - Oaklee Housing Association - one of the largest and most successful housing associations in Northern Ireland. In spite of Oaklee’s reputation, there was considerable concern in the community about the moving of responsibility for the project from the NIHE to Oaklee, which could have derailed the constructive relationship among the stakeholders. Many concerns where expressed from residents 
when Oaklee came on board (concern over high rents, lack of consultation, lack of awareness of new personnel) and this instigated a period of confidence building on behalf of Oaklee with residents.

The Cluain Mór development progressed rapidly after this with most of the original residents moving to this new development. The good relationships between stakeholders, the use of the Mackies site and the placement strategy were regarded as successful. Residents stayed involved over a long period of time and were able to 'professionalize' the structure of the CRA with staff and premises providing the NIHE and Oaklee a direct consultation mechanism but allowed them to leverage support materially and psychologically from the wider west Belfast community.

\section{Fatima Mansions: Medium Complexity}

The Fatima Mansions project is located in the southwest section of Dublin City, relatively near to the city center, consisting mainly of local authority constructed and managed flats. While the location is prime in terms of access to city-based amenities, jobs and transport systems, the area has a reputation for crime, drug-dealing and other anti-social behavior that is one of the worst in the country. Originally consisting of 363 flats and 11 acres, Fatima Mansions represents a medium-sized project in Dublin and, at the end of 2004, the project to regenerate the area was just getting underway, with about $1 / 3^{\text {rd }}$ of the original fourteen apartment blocks demolished, residents moved out and the redevelopment plan approved and project managers in place. While the project was originally conceived as a local authority one, in 2003 a decision was made to reconfigure the project as a public-private partnership (PPP) and to seek bidders to carry out the plans that had been agreed after protracted negotiations among residents, the local authority and elected officials. 
In 2004 Moritz-Elliot, a joint venture between Moritz holdings and P. Elliot Construction (Ltd), was selected to complete the project, with the local authority playing more of a facilitating, rather than an active implementation role going forward. In the course of this shift to private sector implementation responsibility, some of the original plans were changed, notably the mix of public and private housing shifted significantly from a 50\%/50\% split between social and private/affordable in 2001 to a 25\%/75\% split in 2004. Furthermore, the planned density of the area was increased from 500 to 600 dwellings. The overall effect of the current plan will be to decrease by $60 \%$ the number of social housing dwellings in the area (from 363 to 150) and to add a large number of private and affordable dwellings (380 private and 70 affordable). It is important to note, however, that in 2000 , when the first plans for regeneration were being developed, just 255 of the 363 social housing flats were occupied. By August 2004, only 150 units remained occupied as residents had already begun to move to other local authority dwellings to facilitate the first phases of demolition. Furthermore, the community-based Fatima Regeneration Board (FRB) was consulted as part of the changeover process and agreed to the changes after several community amenities were added.

In order to understand the context for the regeneration project in Fatima Mansions it is helpful to sketch out some of the history of the area and the changes that impacted on it. Following the initial construction of 14 four-story flat complexes in 1951, the development "housed a successful working-class community for a [two] decades, forming a small part of the complex social fabric of the inner city with close ties to the industrial economic functions of the immediate area” (Punch et al 2004:12). 
However, the early 1970s brought a severe recession, with many of the traditional industries closing up or moving out of the city, leaving a concentration of low-skilled unemployed in the area. The protracted recession and high-levels of unemployment, along with an unravelling of the social fabric due to drugs, emigration, and misguided government policies such as the 'surrender grants' of the 1980s left the area a virtual wasteland of boarded-up flats, drug-dealing and criminal gangs. The physical refurbishment of the flats by Dublin City Council in the late 1980s “did nothing to halt the decay of the estate or improve other aspects of the quality of life (Fahey 1999: 5).

In 1995, the local authority established the Fatima Task Force, made up of a number of community groups and statutory agencies, with the aim of tackling the socioeconomic issues in the community. Around the same time another community-based ‘uber-group’ was formed - Fatima Groups United - which had similar aims to the Fatima Task Force, but was made up of a wider set of community and voluntary groups and did not include the statutory representatives. Over time, Fatima Groups United (FGU) emerged as the representative ‘voice’ of the community and, in 2000, this group prepared a key document outlining the aims of the community for regeneration and a vision of how residents and other stakeholders could be included in the decision-making processes going forward. The document was titled "Eleven Acres, Ten Steps” and contained a list of ten strategic goals for the area. The goals had little to do with physical regeneration, but all had social and/or process elements that FGU felt were crucial to achieving a turn-around in the area. Many of these principals and aims were incorporated into the first 'Master Plan' for the project developed by the local authority in 2001, entitled "Regeneration / New Generation", which marked the official beginning of the project. 
During 2000, however, other changes were occurring that were to have significant impact on the current structure and aims of the project. The Government passed the Planning and Development Act (2000) which made numerous changes to the legislation governing development, including a new provision allowing local authorities to reserve up to $20 \%$ of all new developments for social and affordable housing. Though this was modified to the advantage of the private sector in a 2002 amendment, the change put developers on notice that the government was serious about increasing the output of social housing and that the private sector was going to have to contribute. Furthermore, the Act underpinned the shift towards mixed developments of social and private housing as a strategic direction in housing provision.

In addition, public-private partnerships (PPPs) were included as an important element of the National Development Plan 2000-2006 (NDP) that would speed up the provision of badly needed infrastructure and decrease demands on the Exchequer.

The Department of Finance encouraged the various departments to ramp up their use of PPPs, with the effect that the Department of the Environment and Local Government created a special unit to identify likely projects that would benefit from this kind of structure. Under these circumstances, it is unsurprising that Dublin City Council decided to change to a PPP structure for the Fatima Mansions project in 2003, in spite of local opposition at the time.

Finally, the Eleven Acres, Ten Steps document recommended that a Fatima Regeneration Board replace the Fatima Task Force as the main (community-based) 
governance body for the project. On this board were to be an equal number of community representatives (four) from each of the Fatima Mansions estate and the surrounding Rialto area. This was seen as a crucial step in achieving better lines of communication and trust among residents of the two areas as well as facilitating integrated decision-making. In addition, an equal number of representatives from the political sphere and relevant local authority (2 each) were on the Board, with a chairman from outside this group to be selected by the group itself. This Board was established as part of the master plan and was still functioning at the end of the case study (2005). The main players in the project were: 1) Dublin City Council with responsibility for monitoring the fulfilment of the terms of the PPP contract and facilitating the regeneration process as required, 2) Moritz/Elliot with responsibility for delivering on the agreed plan and 3) the Fatima Regeneration Board with responsibility for representing the aims of the community during the implementation phase and facilitating ongoing communication among the various stakeholders in the area.

\section{Hardwicke Street: Low Complexity}

The Hardwicke Street project is the smallest and least complex of the three cases. The project encompassed the regeneration of 11 blocks and 210 flats in Dublin's 'northside' and was managed directly by the local authority throughout its duration. There were a minimal number and range of stakeholders involved, namely the local authority, the residents and the construction company who won the tender. The total time required from the start of the project (1999) to its conclusion (2005) was relatively short. 
In the 1980's the Hardwicke Street area became a relatively dangerous part of the city, with high levels of drug-use, stealing and dumping of cars and other anti-social and criminal activity. By the late 1990s it became clear that the entire area needed to be redeveloped as a matter of urgency. The first decision to include Hardwicke Street in a program of redevelopment was made by Dublin Corporation in 1997 following the allocation of government funds for regeneration and the introduction of a new government policy of localization; "Better Local Government". However, it was not until 1999 that the project really got underway and initial consultations were made with the community. A year later Dublin Corporation went through a significant reorganization, and Hardwicke Street became part of the "North East Inner City" area and services with the community came under the remit of the local (DCC) office for that area.

The reorganization of Dublin Corporation created some uncertainty and the appointment of a local housing manager, to work out of the local office established in 2000 produced boundary-spanning opportunities between the local authority and the local community. Recognizing that many of the residents lived in a "climate of fear" and that some groups that had claimed to represent the community did not have the support of ordinary citizens, DCC and a number of legitimate community stakeholders commissioned an independent research body to assess the needs of the area and to ensure that the regeneration plan took a holistic approach to the social, economic and structural issues that existed. Once the survey was completed in 2002, the project went to tender and Dublin City Council reviewed seven tenders for the job, as specified by the Council's Deputy City Architect. Following the selection of Foreman Construction (Ireland) Ltd to undertake the regeneration, the project leadership processes reverted to more or less standard administrative processes. With 
minimal changes, apart from going over budget by roughly $40 \%$ - not unusual in the Celtic Tiger economy of the time, the project was completed in three years.

\section{Connswater: Low Complexity}

The Connswater area is located within the 'Island' local Government electoral ward of East Belfast (identified by the Northern Ireland Housing Executive (NIHE) as Belfast 2). The Island ward is made up of a large industrial site that was previously part of the Harland and Woolf shipyard, which - after years of neglect - was targeted for regeneration and is now known as 'Titanic quarter'. The remaining part of the ward (about 25\%) is the Connswater area.

This area had consistently been identified as having some of the worst levels of poverty and deprivation in Northern Ireland emerging as the $34^{\text {th }}$ worst out of 582 wards in Northern Ireland in terms of the Noble indicators ${ }^{8}$ in the period studied. The area is strongly unionist and virtually all the residents are Protestant. While there were low vacancy rates, the population was aging and the school roll was dropping. At the time of the study, the total population was 1800 people.

In 1998, based upon the findings in the Northern Ireland House Condition Survey of 1996, the NIHE determined that approximately 500 terraced houses in the Connswater area should be targeted for regeneration. However, in order to avoid speculative buying in advance of regeneration, the decision was not made public until the redevelopment plan was well advanced and vesting was applied for in 1999. The first time that local residents or politicians were notified of the redevelopment plans was the distribution of leaflets informing the community of the application for the vesting order. 
In response, residents and politicians formed the Mersey Street Area Residents Association (MARA) in September 1999 to discuss local concerns about redevelopment and to generate ideas as to how the community could make its concerns known to the authorities. MARA received funding assistance and support from both the East Belfast Partnership Board (via the East Belfast Community Development Association and the International Fund for Ireland ${ }^{9}$. By April 2001, MARA succeeded in putting together a document detailing the concerns of local residents and business, including a 'ten--point plan' for future engagement with the NIHE. The document addressed a range of issues including specific physical requirements for housing and area layout, a request for affordable housing, and consultation and development process recommendations. In addition to the points in the ten-point plan, residents raised serious concerns about the decision to close the Mersey Street Primary School in the face of declining enrolment.

Phase I of the project had been completed in late 2001, consisting of demolition of existing dwellings and the construction of 33 new social housing units by Connswater Housing Association. Phase II got going in 2002 and incorporated nine of the ten points raised by MARA and included the construction of 55 new dwellings. This second phase was scheduled for completion in early 2006 (after the completion of the case study).

\section{Endnotes for Supplement}

1. The area containing Roden Street is the local government Blackstaff Ward which has lost over 20 per cent of its population in ten years between the censuses of 1991 and 2001, and was rated one of the worst in the country in terms of the Noble index of multiple deprivation. 
2. See Power (2000), Norris (2001) and Somerville-Woodward (2002)

3. Now called Dublin City Council

\section{References for Supplement}

Power, Sinead. 2000. The development of the Ballymun housing scheme, Dublin 1965-1969, Irish Geography 33: 199-212

Norris, Michelle. 2001. Privatizing Public housing estate regeneration: A case study of Ballymun Regeneration Ltd, Dublin. Paper presented at the Irish Social Policy Association/Social Policy Association Conference 'Development, Regeneration and Social Policy’, July 26-28, Dublin, Ireland.

Somerville-Woodward, Robert. 2002. Ballymun: A History, Volume 2, c. 1960-2001, Dublin: Ballymun Regeneration Ltd. 
Appendix 1

\begin{tabular}{|c|c|c|}
\hline Leadership practice & Source & Exemplary data \\
\hline \multicolumn{3}{|l|}{ Adaptive } \\
\hline $\begin{array}{l}\text { A) Stimulating innovative } \\
\text { ideas and new ways of } \\
\text { working; [8] }\end{array}$ & $\begin{array}{l}\text { Roden Street (Interview- } \\
\text { NIHE Representative) }\end{array}$ & $\begin{array}{l}\text { 'A couple of people } \\
\text { working in parallel with } \\
\text { the South Belfast } \\
\text { Partnership Board came } \\
\text { to a decision to bring } \\
\text { people to a consensus - } \\
\text { that was the birth of GVRT } \\
\text { in 1999/2000'. }\end{array}$ \\
\hline $\begin{array}{l}\text { B) actively supporting the } \\
\text { inclusion of diverse skills / } \\
\text { perspectives (including } \\
\text { boundary-spanning); [23] }\end{array}$ & $\begin{array}{l}\text { Fatima - (Interview: Local } \\
\text { Authority Representative) }\end{array}$ & $\begin{array}{l}\text { "The process of agreement } \\
\text { was part of a continued } \\
\text { engagement with the } \\
\text { interests of the residents" }\end{array}$ \\
\hline $\begin{array}{l}\text { C) changing plans, } \\
\text { processes, routines in } \\
\text { response to tensions [14] }\end{array}$ & $\begin{array}{l}\text { Ballymun - (Interview - } \\
\text { Ballymun Regeneration } \\
\text { Ltd Representative) }\end{array}$ & $\begin{array}{l}\text { Altering the initial process } \\
\text { - "to knit Ballymun back } \\
\text { into the fabric of the city" }\end{array}$ \\
\hline \multicolumn{3}{|l|}{ Enabling (Dualities) } \\
\hline $\begin{array}{l}\text { D.1) acting to reduce } \\
\text { conflict; 'buffering' tension } \\
\text { [8] }\end{array}$ & $\begin{array}{l}\text { Hardwicke Street - } \\
\text { (Interview - Area Housing } \\
\text { manager) }\end{array}$ & $\begin{array}{l}\text { "the estate manager acts } \\
\text { like a buffer between the } \\
\text { tenants and those involved } \\
\text { in the regeneration } \\
\text { process..." }\end{array}$ \\
\hline \multicolumn{3}{|l|}{$V S$} \\
\hline $\begin{array}{l}\text { D.2 injecting tension / } \\
\text { conflict; [5] }\end{array}$ & $\begin{array}{l}\text { Connswater - (Interview } \\
\text { with resident) }\end{array}$ & $\begin{array}{l}\text { "there is a suggestion that } \\
\text { tenants felt under pressure } \\
\text { from NIHE to accept } \\
\text { alternative housing with } \\
\text { few choices available and }\end{array}$ \\
\hline
\end{tabular}




\begin{tabular}{|c|c|c|}
\hline & & $\begin{array}{l}\text { with the alternative of not } \\
\text { being housed at all if they } \\
\text { didn't agree" }\end{array}$ \\
\hline $\begin{array}{l}\text { E.1) giving meaning to } \\
\text { events (sense-making and } \\
\text { sense-giving)[11] }\end{array}$ & $\begin{array}{l}\text { Clonard - (Interviewee - } \\
\text { NIHE Representative) }\end{array}$ & $\begin{array}{l}\text { A recognition on behalf of } \\
\text { the NIHE that it was a } \\
\text { community with a unique } \\
\text { history and this had to be a } \\
\text { factor in regeneration } \\
\text { process - “The area has a } \\
\text { strong community } \\
\text { infrastructure. It's very } \\
\text { proud and very political”. }\end{array}$ \\
\hline \multicolumn{3}{|l|}{ VS } \\
\hline $\begin{array}{l}\text { E.2 disrupting existing } \\
\text { patterns and } \\
\text { assumptions;[11] }\end{array}$ & $\begin{array}{l}\text { Ballymun - (Interview - } \\
\text { Community organizer). }\end{array}$ & $\begin{array}{l}\text { For the first time, the 'do } \\
\text { nothing' response was } \\
\text { understood to be untenable } \\
\text { - "The publication of the } \\
\text { Craig Gardiner Report in } \\
\text { August } 1993 \text { marked a } \\
\text { watershed in the history of } \\
\text { Ballymun" laying out a } \\
\text { range of options for a new } \\
\text { future for the area. }\end{array}$ \\
\hline $\begin{array}{l}\text { F.1) coordinating and } \\
\text { formalising networks [6] }\end{array}$ & $\begin{array}{l}\text { Clonard - (Interview- } \\
\text { NIHE Representative) }\end{array}$ & $\begin{array}{l}\text { "The housing officer was } \\
\text { very important in creating } \\
\text { the communication with } \\
\text { residents" }\end{array}$ \\
\hline
\end{tabular}




\begin{tabular}{|c|c|c|}
\hline VS & & \\
\hline $\begin{array}{l}\text { F.2 facilitating and } \\
\text { enabling informal } \\
\text { networks;[3] }\end{array}$ & $\begin{array}{l}\text { Roden Street - (Interview } \\
\text { with NIHE representative) }\end{array}$ & $\begin{array}{l}\text { "The organizations are } \\
\text { interacting after our } \\
\text { initiations" }\end{array}$ \\
\hline $\begin{array}{l}\text { G.1) removing, excluding } \\
\text { or alienating dissenting } \\
\text { actors [2] }\end{array}$ & $\begin{array}{l}\text { Connswater - (Interview - } \\
\text { Housing Association } \\
\text { member) }\end{array}$ & $\begin{array}{l}\text { "The first thing we knew } \\
\text { about it was when leaflets } \\
\text { were put through } \\
\text { letterboxes. Even local } \\
\text { politicians knew nothing } \\
\text { about it" }\end{array}$ \\
\hline$V S$ & & \\
\hline $\begin{array}{l}\text { G.2 protecting people / } \\
\text { ideas from external politics } \\
\text { and top-down directives } \\
\text { [4] }\end{array}$ & $\begin{array}{l}\text { Clonard - (Interview - } \\
\text { Residents Group Member) }\end{array}$ & $\begin{array}{l}\text { "The chairperson .... he } \\
\text { used to be a builder. That } \\
\text { was very good, he knew } \\
\text { what he was doing. They } \\
\text { couldn't just tell him } \\
\text { anything. His daughter is } \\
\text { still involved". }\end{array}$ \\
\hline Administrative & & \\
\hline $\begin{array}{l}\text { H) directing, planning and } \\
\text { resourcing activities; [16] }\end{array}$ & $\begin{array}{l}\text { Ballymun -The Ballymun } \\
\text { Masterplan }\end{array}$ & $\begin{array}{l}\text { The Ballymun Masterplan } \\
\text { with } 31 \text { chapters covering } \\
\text { every aspect of the plans } \\
\text { for the area: from } \\
\text { education to energy, } \\
\text { transport to training and } \\
\text { education, and economic } \\
\text { development to } \\
\text { community facilities. }\end{array}$ \\
\hline
\end{tabular}




\begin{tabular}{|l|l|l|}
\hline $\begin{array}{l}\text { I) creating clear lines of } \\
\text { authority, roles and } \\
\text { responsibilities; [13] }\end{array}$ & $\begin{array}{l}\text { Hardwicke Street - Project } \\
\text { documentation }\end{array}$ & $\begin{array}{l}\text { 'The North West Inner } \\
\text { City Area Housing Office } \\
\text { was opened in July 2000, } \\
\text { providing a range of } \\
\text { services dealing with } \\
\text { needs as diverse as } \\
\text { housing allocations and } \\
\text { transfers, maintenance, } \\
\text { welfare and environmental } \\
\text { issues. This office deals } \\
\text { with all City Council } \\
\text { services in the area, } \\
\text { particularly housing and } \\
\text { community services' }\end{array}$ \\
\hline $\begin{array}{l}\text { J) integrating and } \\
\text { embedding innovation into } \\
\text { the formal system [14] }\end{array}$ & Authority Representative) & $\begin{array}{l}\text { "We tried to build on as } \\
\text { much of their plan (Eleven } \\
\text { aches, ten steps) as } \\
\text { possible, we went out of } \\
\text { our way to build a } \\
\text { relationship...” }\end{array}$ \\
\hline
\end{tabular}

Figure 1: Adaptive, administrative and enabling leadership practices 


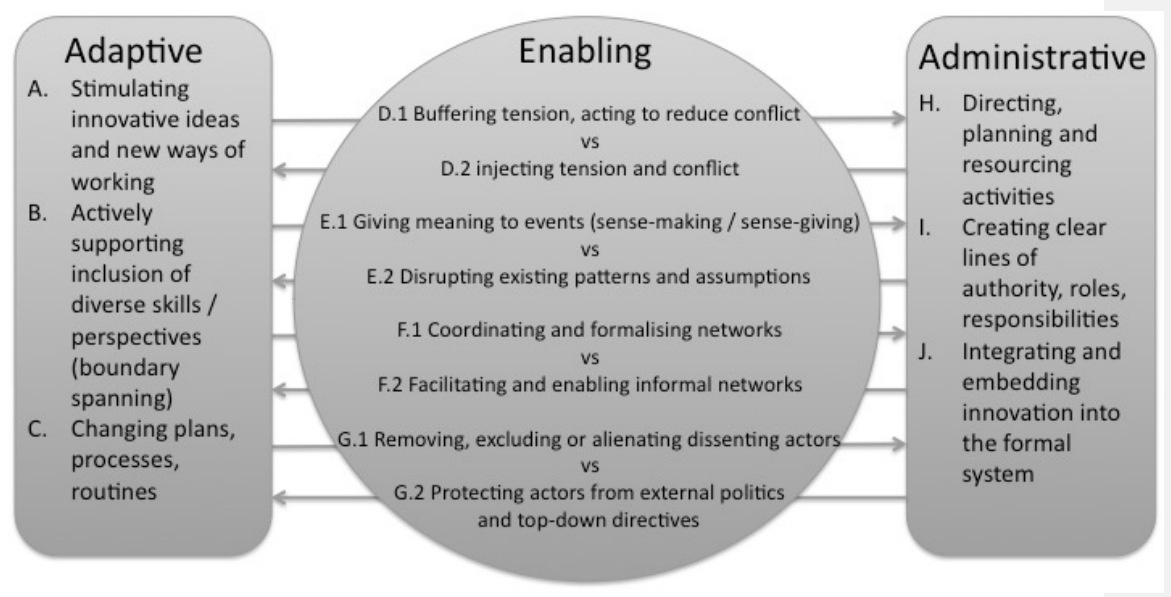


Table 1 : Classifying urban regeneration complexity by diversity and duration

\begin{tabular}{|c|c|c|}
\hline \multicolumn{3}{|c|}{ Urban Regeneration } \\
\hline $\begin{array}{l}\text { Case and level of } \\
\text { Complexity }\end{array}$ & Diversity & Duration \\
\hline \multicolumn{3}{|l|}{ HIGH COMPLEXITY } \\
\hline $\begin{array}{l}\text { Roden Street/Greater } \\
\text { Village (Northern } \\
\text { Ireland) }\end{array}$ & $\begin{array}{l}\text { Large } \text { / Small } \\
\text { - } \text { Multiple different communities } \\
\text { and community groups } \\
\text { - Multiple political actors } \\
\text { - Two proposed phases (111 } \\
\text { dwellings demolished followed } \\
\text { by } 1500 \text { demolished) } \\
\text { - Funding shift from NIHE to } \\
\text { - Housing Association provider } \\
\text { History of division, } \\
\text { paramilitarism and sectarian } \\
\text { conflict }\end{array}$ & $\begin{array}{l}\text { Short / Long } \\
\text { (Endnote 3) } \\
\text { - } \\
\text { Long } \\
\text { gestation } \\
\text { period, } 7 \\
\text { years to get } \\
\text { outcome in } \\
\text { phase 1, } \\
\text { phase 2 } \\
\text { ongoing }\end{array}$ \\
\hline $\begin{array}{l}\text { Ballymun } \\
\text { (Republic of Ireland) }\end{array}$ & 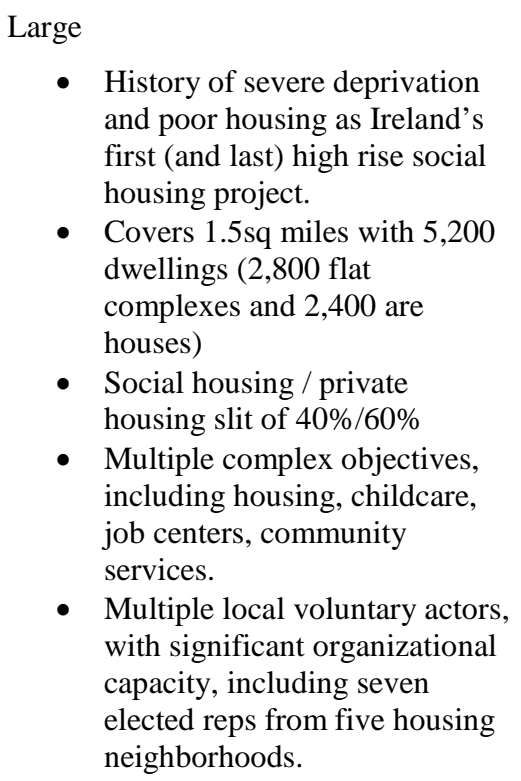 & $\begin{aligned} \text { Long } & \\
\text { - } & \text { Initiated in } \\
& 1997 \\
\text { - } & 10 \text { year plan }\end{aligned}$ \\
\hline $\begin{array}{l}\text { MEDIUM } \\
\text { COMPLEXITY }\end{array}$ & & \\
\hline $\begin{array}{l}\text { Clonard (Northern } \\
\text { Ireland) }\end{array}$ & $\begin{array}{l}\text { Medium } \\
\text { • Four phases involving }\end{array}$ & $\begin{array}{l}\text { Medium } \\
\bullet \quad 7 \text { years from }\end{array}$ \\
\hline
\end{tabular}




\begin{tabular}{|c|c|c|}
\hline & $\begin{array}{l}\text { replacement of } 650 \text { dwellings } \\
\text { with } 200 \\
\text { - Long political history of } \\
\text { community cohesion within the } \\
\text { context of the NI conflict and } \\
\text { sectarian violence } \\
\text { - A significant number of agents } \\
\text { involved, including community } \\
\text { group, political reps, NIHE and } \\
\text { housing association } \\
\text { - Funding shift from NIHE to } \\
\text { housing association }\end{array}$ & $\begin{array}{l}\text { initial } \\
\text { negotiations } \\
\text { to completion } \\
\text { of both } \\
\text { phases }\end{array}$ \\
\hline $\begin{array}{l}\text { Fatima Mansions } \\
\text { (Republic of Ireland) }\end{array}$ & $\begin{array}{l}\text { Medium } \\
\text { - Close to Dublin city center but } \\
\text { with reputation and history as } \\
\text { high crime, drug dealing and } \\
\text { antisocial behavior. } \\
\text { - Originally comprised of } 363 \\
\text { flats and } 11 \text { acres } \\
\text { - } \quad \text { Well organized and collective } \\
\text { local voluntary and community } \\
\text { sector working together } \\
\text { (Fatima Groups United). } \\
\text { - Significant legislative change } \\
\text { with provisions for social } \\
\text { housing }\end{array}$ & $\begin{array}{l}\text { Medium } \\
\text { - Six year } \\
\text { duration, } \\
\text { initiating in } \\
2000\end{array}$ \\
\hline \multicolumn{3}{|l|}{ LOW COMPLEXITY } \\
\hline $\begin{array}{l}\text { Hardwicke Street } \\
\text { (Republic of Ireland) }\end{array}$ & $\begin{array}{ll}\text { Small } & \\
\text { - } & \text { Regeneration and replacement } \\
\text { of } 210 \text { apartments } \\
\text { - } & \text { Minimal range of stakeholders } \\
\text { involved } \\
\text { - } \\
\text { High levels of conflict and } \\
\text { deprivation }\end{array}$ & $\begin{aligned} \text { Short } & \\
\text { - } & 5 \text { years from } \\
& \text { initial } \\
& \text { negotiations } \\
& \text { to completion }\end{aligned}$ \\
\hline $\begin{array}{l}\text { Connswater } \\
\text { Northern Ireland }\end{array}$ & $\begin{array}{cl}\text { Small } & \\
\text { - Located within large industrial } \\
\text { site previous part of Harland } \\
\text { and Woolf shipyard } \\
\text { - } \\
\text { Identified as having some of } \\
\text { the worst levels of poverty and } \\
\text { deprivation in NI (Endnote 4) } \\
\text { - } \quad \text { Phase } 1 \& 2 \text { saw the vesting of }\end{array}$ & $\begin{array}{cl}\text { Short } & \\
\text { - } & \text { Five year } \\
\text { duration } \\
\text { (2000 to } \\
\text { 2005). }\end{array}$ \\
\hline
\end{tabular}




\begin{tabular}{|l|l|l|}
\hline & $\begin{array}{l}\text { the original } 489 \text { properties and } \\
\text { the construction of } 88 \text { in their } \\
\text { place. }\end{array}$ & $\begin{array}{l}\text { Strongly unionist and } \\
\text { protestant community with } \\
\text { significant issues around } \\
\text { sectarianism / racism. }\end{array}$ \\
\hline
\end{tabular}


Figure 2: Number of instances of adaptive, administrative and enabling practices by case

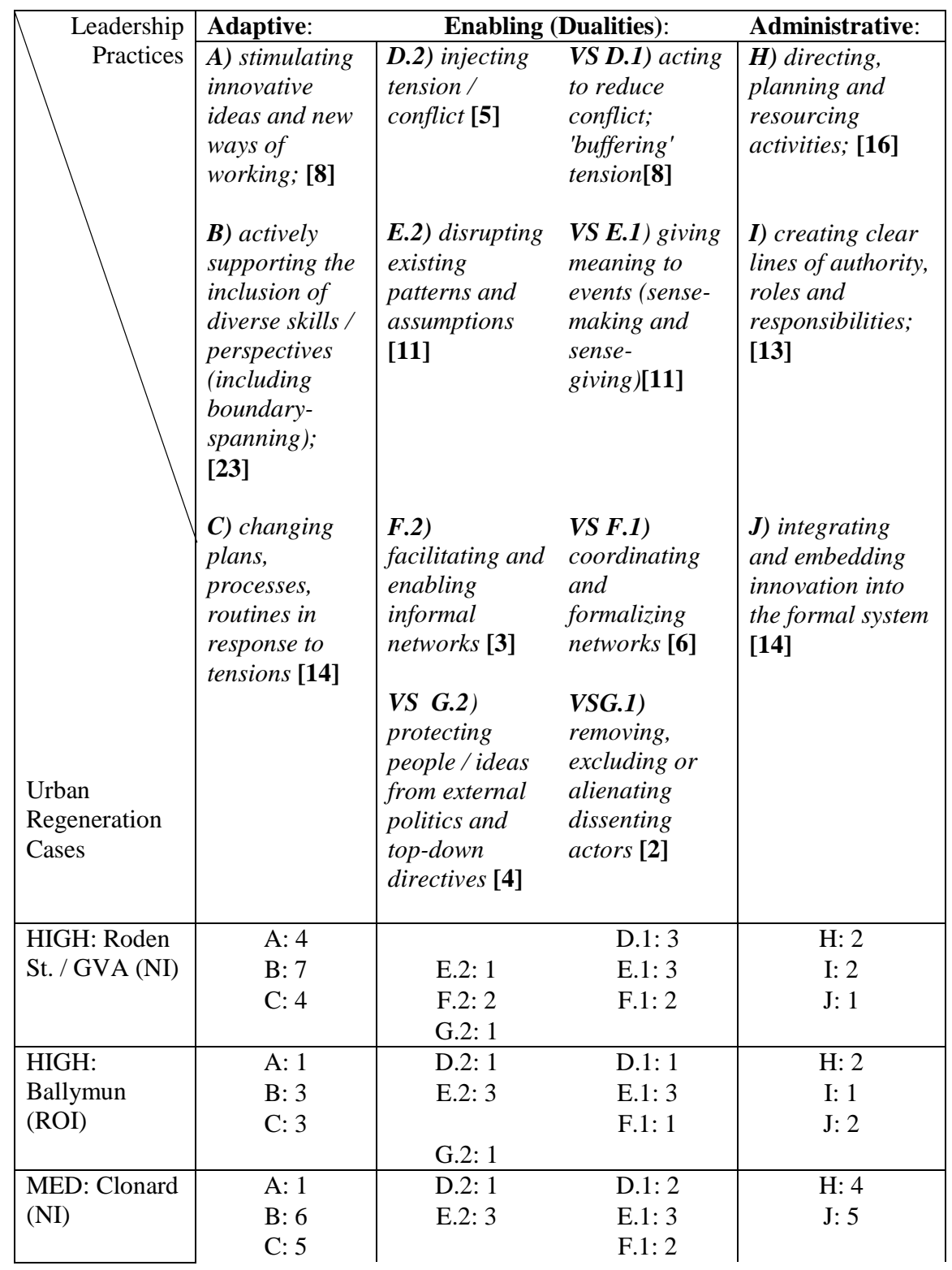




\begin{tabular}{|l|c|cc|c|}
\hline & & G.2: 1 & G.1: 1 & \\
\hline MED: Fatima & A: 2 & D.2: 1 & D.1: 1 & H: 3 \\
(ROI) & B: 4 & E.2: 2 & E.1: 1 & I: 1 \\
& C: 1 & & F.1: 1 & J: 3 \\
\hline LOW: & B: 1 & D.2: 1 & & H: 2 \\
Connswater & C: 1 & F.2: 1 & & I: 1 \\
(NI) & & & G.1: 1 & J: 2 \\
\hline LOW: & B: 2 & & D.1:1 & H:3 \\
Hardwicke St. & & & & \\
(ROI) & & E.2:2 & E.1: 1 & I:3 \\
& & & & J:1 \\
\hline
\end{tabular}

